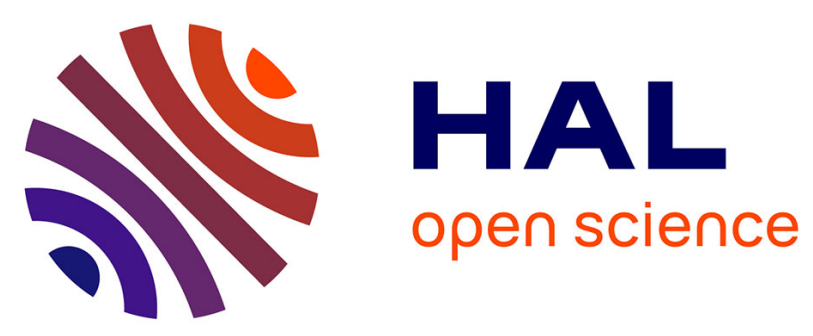

\title{
Benzo[a]pyrene-induced DNA damage associated with mutagenesis in primary human activated $\mathrm{T}$ lymphocytes
}

Marie Liamin, Elisa Boutet-Robinet, Emilien L. Jamin, Morgane Fernier, Laure Khoury, Benjamin Kopp, E. Le Ferrec, Julien Vignard, Marc Audebert, Lydie Sparfel

\section{To cite this version:}

Marie Liamin, Elisa Boutet-Robinet, Emilien L. Jamin, Morgane Fernier, Laure Khoury, et al.. Benzo[a]pyrene-induced DNA damage associated with mutagenesis in primary human activated $\mathrm{T}$ lymphocytes. Biochemical Pharmacology, 2017, 137, pp.113-124. 10.1016/j.bcp.2017.04.025 . hal01560145

HAL Id: hal-01560145

https://hal-univ-rennes1.archives-ouvertes.fr/hal-01560145

Submitted on 13 Jul 2017

HAL is a multi-disciplinary open access archive for the deposit and dissemination of scientific research documents, whether they are published or not. The documents may come from teaching and research institutions in France or abroad, or from public or private research centers.
L'archive ouverte pluridisciplinaire HAL, est destinée au dépôt et à la diffusion de documents scientifiques de niveau recherche, publiés ou non, émanant des établissements d'enseignement et de recherche français ou étrangers, des laboratoires publics ou privés. 


\section{Benzo[a]pyrene-induced DNA damage associated with mutagenesis in primary human activated $\mathrm{T}$ lymphocytes}

Marie Liamin ${ }^{1,2}$, Elisa Boutet-Robinet ${ }^{3}$, Emilien L. Jamin ${ }^{3}$, Morgane Fernier ${ }^{1,2}$, Laure Khoury $^{3}$, Benjamin Kopp ${ }^{3}$, Eric Le Ferrec ${ }^{1,2}$, Julien Vignard ${ }^{3}$, Marc Audebert ${ }^{3}$ and Lydie Sparfel $^{1,2}$

${ }^{1}$ Institut National de la Santé et de la Recherche Médicale (INSERM), Institut de Recherche en Santé, Environnement et Travail (IRSET - INSERM UMR 1085), 35000 Rennes, France; ${ }^{2}$ Université de Rennes 1, Faculté des Sciences Pharmaceutiques et Biologiques, structure fédérative de recherche Biosit UMS CNRS 3480/US INSERM 018, 35043 Rennes, France ; ${ }^{3}$ Toxalim (Research Center in Food Toxicology), Université de Toulouse, INRA, ENVT, INPPurpan, UPS, Toulouse, France

Corresponding author: Lydie Sparfel, IRSET- INSERM UMR 1085 Université de Rennes 1, 2 avenue du Pr Léon Bernard, 35043 Rennes, France. Telephone: +33 2232347 63; Fax: +332232347 94; e-mail: lydie.sparfel@univ-rennes1.fr

Abbreviations: AhR, aryl hydrocarbon receptor ; AMC, 7-amino-4-methylcoumarin ; $\alpha$-NF, alpha-naphthoflavone ; ATM, ataxia telangiectasia mutated ; $\mathrm{B}[a] \mathrm{P}$, benzo $[a]$ pyrene ; $\mathrm{BPDE}$, B $[a]$ P diol epoxide ; CYPs, cytochromes P-450; DMSO, dimethyl sulfoxide; DDR, DNA damage response; DSBs, double-strand breaks ; EROD, ethoxyresorufin deethylase ; FPG, formamido pyrimidine glycosylase; HR, homologous recombination; PAHs, polycyclic aromatic hydrocarbons 


\section{Abstract}

Polycyclic Aromatic Hydrocarbons (PAHs), such as benzo $[a]$ pyrene $(\mathrm{B}[a] \mathrm{P})$, are widely distributed environmental contaminants exerting toxic effects such as genotoxicity and carcinogenicity, mainly associated with aryl hydrocarbon receptor (AhR) activation and the subsequent induction of cytochromes P-450 (CYP) 1-metabolizing enzymes. We previously reported an up-regulation of AhR expression and activity in primary cultures of human $\mathrm{T}$ lymphocyte by a physiological activation. Despite the suggested link between exposure to PAHs and the risk of lymphoma, the potential of activated human $\mathrm{T}$ lymphocytes to metabolize AhR exogenous ligands such as $\mathrm{B}[a] \mathrm{P}$ and produce DNA damage has not been investigated. In the present study, we characterized the genotoxic response of primary activated $\mathrm{T}$ lymphocytes to $\mathrm{B}[a] \mathrm{P}$. We demonstrated that, following $\mathrm{T}$ lymphocyte activation, $\mathrm{B}[a] \mathrm{P}$ treatment triggers a marked increase in CYP1 expression and activity generating, upon metabolic activation, DNA adducts and double-strand breaks (DSBs) after a 48-h treatment. At this time point, $\mathrm{B}[a] \mathrm{P}$ also induces a DNA damage response with ataxia telangiectasia mutated kinase activation, thus producing a p53-dependent response and $\mathrm{T}$ lymphocyte survival. $\mathrm{B}[a] \mathrm{P}$ activates DSB repair by mobilizing homologous recombination machinery but also induces gene mutations in activated human $\mathrm{T}$ lymphocytes which could consequently drive a cancer process. In conclusion, primary cultures of activated human $\mathrm{T}$ lymphocytes represent a good model for studying genotoxic effects of environmental contaminants such as PAHs, and predicting human health issues.

Key words: activated human T lymphocytes, benzo[a]pyrene, DNA Damage Response 
Chemical coumpounds studied in this article

benzo[a]pyrene (PubChem CID: 2336); alpha-naphtoflavone (PubChem CID: 11790); 2morpholin-4-yl-6-thianthren-1-yl-pyran-4-one (KU-55933) (PubChem CID: 5278396); dimethyl sulfoxide (PubChem CID: 679); potassium bromate (PubChem CID: 23673461) 


\section{Introduction}

Polycyclic aromatic hydrocarbons (PAHs) constitute a major class of environmental contaminants to which humans are commonly exposed. They are formed by incomplete combustion of organic materials and are notably found in large amounts in diet, air pollution, cigarette smoke and some occupational atmospheres [1]. PAHs exert various toxic effects towards human health, including carcinogenic and immunosuppressive effects, and contribute to smoking-related diseases [2]. Most of these effects have been linked to the activation of the aryl hydrocarbon receptor (AhR) and subsequent transcription of AhR-regulated genes. Among PAHs, benzo $[a]$ pyrene $(\mathrm{B}[a] \mathrm{P})$ is the most widely used model compound for studying the effects of carcinogenic PAHs. $\mathrm{B}[a] \mathrm{P}$ is not only agonist for $\mathrm{AhR}$, but also substrate for the induced xenobiotic metabolizing enzymes from the cytochromes P-450 (CYPs) 1 family [3]. CYP1 isoforms, metabolize $\mathrm{B}[a] \mathrm{P}$ to epoxide derivatives that can covalently bind DNA to form DNA adducts; the predominant form results from addition of $\mathrm{B}[a] \mathrm{P}$ diol epoxide (BPDE) to the $\mathrm{N}^{2}$ exocyclic amino group of guanine to form a dG-N ${ }^{2}$-BPDE adduct [4]. DNA damage has been regarded as an important factor in chemical carcinogenesis, and DNA adducts derived from $\mathrm{B}[a] \mathrm{P}$ are believed to be a critical event in tumour formation by producing mutations in critical genes such as the tumour suppressor p53 [5]. Thus, emphasis has been placed on the DNA-damaging properties of $\mathrm{B}[a] \mathrm{P}$, the only one PAH classified as carcinogenic to humans for lung, skin and bladder tumours by the International Agency of Research on Cancer [6]. In addition, $\mathrm{B}[a] \mathrm{P}$ induces cancer development in lymphoid tissue and hematopoietic compartment in animals [7], and some epidemiological studies have suggested a potential role of $\mathrm{B}[a] \mathrm{P}$ in the development of lymphomas in humans [8].

Human blood peripheral lymphocytes, in particular T lymphocytes, have been reported to possess CYP1A1 and 1B1-metabolizing systems [9], suggesting thus that it could be an useful model for studying the potential of PAHs such as $\mathrm{B}[a] \mathrm{P}$ to be metabolized, bind DNA, 
and form different types of DNA adducts linked to the susceptibility seen in the induction of human cancers [10]. Whereas a significant association has been found between the level of BPDE-induced DNA adducts in T lymphocyte-enriched peripheral blood mononuclear cell cultures and risk for cancer [11], studies on the relationship between $\mathrm{B}[a] \mathrm{P}$ metabolism and its DNA-damaging potential linked to cancer risk have provided equivocal results in these $\mathrm{T}$ lymphocytes-enriched cultures [12]. This is in part due to the observation that such cultured T lymphocytes are poor metabolizers of PAHs such as $\mathrm{B}[a] \mathrm{P}$, exhibiting significant CYP1mediated activity only upon activation by mitogenic lectins such as phytohemagglutinin [13]. As compared with phytohemagglutinin promoting polyclonal $\mathrm{T}$ cell proliferation, $\mathrm{T}$ lymphocyte activation by anti-CD3 and anti-CD28 antibodies represents a more physiologically relevant $\mathrm{T}$ cell stimulation [14], and we have recently reported that AhR is present and functional only in $\mathrm{CD} 3 / \mathrm{CD} 28$-activated $\mathrm{T}$ lymphocytes and not in resting counterparts [15]. Altogether, these data suggest an increased ability of the activated $\mathrm{T}$ lymphocytes to metabolize AhR exogenous ligands such as $\mathrm{B}[a] \mathrm{P}$ and then to produce DNA damage. The present study was designed to explore the genotoxic response to $\mathrm{B}[a] \mathrm{P}$ in these primary $\mathrm{CD} 3 / \mathrm{CD} 28$-activated human $\mathrm{T}$ lymphocytes, a relevant model to human health issues. We report that $\mathrm{B}[a] \mathrm{P}$, upon metabolic activation, generates $\mathrm{dG}-\mathrm{N}^{2}-\mathrm{BPDE}$ adducts and DNA double-strand breaks (DSBs). In human T lymphocytes, this elicits a DNA damage response (DDR) via an ataxia telangiectasia mutated (ATM)-dependent pathway, supporting DNA repair and cell survival to $\mathrm{B}[a] \mathrm{P}$ treatment but leading to gene mutations. 


\section{Materials and methods}

\subsection{Chemicals and reagents}

$\mathrm{B}[a] \mathrm{P}$, alpha-naphthoflavone $(\alpha-\mathrm{NF}), 2$-morpholin-4-yl-6-thianthren-1-yl-pyran-4-one (KU55933), dimethyl sulfoxide (DMSO), potassium bromate, DAPI, ethoxyresorufin, Asp-GluAsp-7-amino-4-methylcoumarin (AMC), and agarose were obtained from Sigma-Aldrich (St. Louis, MO, USA). SYBR Gold nucleic acid stain and carboxy-fluorescein succinimidyl ester (CFSE) were provided by Thermofischer Scientific (Braunschweig, Germany), whereas $\left[{ }^{3} \mathrm{H}\right]-$ methyl-thymidine was purchased from Amersham Biosciences (Buck, UK). Antibodies against CYP1B1, p21, RAD51 and Hsc70, and against CYP1A1 were supplied from Abcam (Paris, France), and Santa Cruz Technology (Heidelberg, Germany), respectively. Antibodies against p53, phospho-p53 (Ser15), phospho-CHK1 (Ser317) and phospho-CHK2 (Thr68) were obtained from Cell Signaling Technology (Saint Quentin, France), while anti-phosphoATM (Ser1981) and anti-phospho-Histone H2AX (Ser139) were from Merck Millipore (Molsheim, France). The 53BP1 antibody was purchased from Novus Biological (Abingdon, UK).

\subsection{Cell culture and treatment}

Peripheral blood mononuclear cells were isolated from blood donor buffy coats (written consent for the use of blood samples for the research protocol obtained according to the regulation for blood transfusion of the French blood organization Etablissement Français du Sang, Rennes (France)) by Ficoll (Thermofischer Scientific) gradient centrifugation. After separation of monocytes by a 1-h adhesion step, $\mathrm{T}$ lymphocytes were purified from nonadherent cells by negative selection using Dynabeads ${ }^{\circledR}$ Untouched $^{\mathrm{TM}}$ Human T Cells Kit (Thermofischer Scientific). T lymphocytes were cultured in RPMI medium (Eurobio, Les Ulis, France) supplemented with $20 \mathrm{IU} / \mathrm{mL}$ penicillin, $20 \mu \mathrm{g} / \mathrm{mL}$ streptomycin, and $10 \%$ 
decomplemented fetal calf serum (Thermofischer Scientific), and stimulated with Dynabeads $^{\circledR}$ T-Expander beads coated with anti-CD3 and anti-CD28 antibodies (Thermofischer Scientific) as previously reported [15]. Chemicals were used as stock solutions in DMSO. The final concentration of DMSO in culture medium was always $<0.2 \%$ $\mathrm{v} / \mathrm{v}$ and control cultures received vehicle containing the same dose of DMSO as treated cultures.

\subsection{RT- $q P C R$}

Total RNA was isolated from $\mathrm{T}$ lymphocytes using the TRIzol method (Thermofischer Scientific) and then reverse-transcribed into cDNA using the RT Applied Biosystems kit (Foster City, CA, USA). qPCR assays were performed using gene-specific primers from Qiagen for CYP1A1, CYP1B1 and growth arrest and DNA damage inducible, alpha (gadd45A) (Courtaboeuf, France) or Eurogentec for the others (Seraing, Belgium) (Table 1). The amplification curves of the PCR products were analyzed with the ABI Prism SDS software using the comparative cycle threshold method. Relative quantification of the steadystate target mRNA levels was calculated after normalization of the total amount of cDNA tested to a $18 \mathrm{~S}$ mRNA endogenous reference as previously described [15].

\subsection{T $^{2}$ Profiler ${ }^{\mathrm{TM}}$ PCR arrays}

The Human DNA Repair RT² ProfilerTM PCR Array was used to profile the expression of 84 key genes encoding the enzymes that repair damaged DNA according to the manufacturer's instructions (SABiosciences, Qiagen). For each condition, we pooled equal amounts of RNAs isolated from DMSO or $\mathrm{B}[a] \mathrm{P}$-treated cultures of $\mathrm{T}$ lymphocytes established from 9 blood donors. Pooling small samples of cells for array analysis is considered advantageous in situations where the level of biological variation could be high compared to technical 
variation on the array $[16,17]$. The amplification curves of the PCR products were analyzed with the ABI Prism SDS software as reported for RT-qPCR. The expression levels of target genes were normalized relative to the expression of $\beta 2$ microglobulin as housekeeping gene and were given as fold change compared with control with vehicle.

\subsection{Western blotting}

Total cellular protein extracts were prepared by lysis of $\mathrm{T}$ lymphocytes as previously described [15]. Proteins were separated on a polyacrylamide gel and electrophoretically transferred onto nitrocellulose membranes (Merck Millipore). After blocking, membranes were incubated with antibodies and immunolabeled proteins were visualized by chemiluminescence using the LAS-3000 analyzer (Fujifilm). For protein loading evaluation, primary antibody against Hsc70 was used. Image processing was performed using MultiGauge software (Fujifilm).

\subsection{CYP activities}

Ethoxyresorufin deethylase (EROD) activity was used as a measurement of CYP1 activities [18]. Briefly, T lymphocytes were incubated in phosphate-buffered saline, $\mathrm{pH} 7.4$, containing $50 \mu \mathrm{M}$ ethoxyresorufin and $1.5 \mathrm{mM}$ salicyclamide and resorufin formation was monitored using a FLUOstar Omega Microplate Reader (BMG Labtech, Ortenberg, Germany). Excitation and emission wavelengths were 544 and $590 \mathrm{~nm}$, and reaction rates were determined under linear conditions. 


\subsection{DNA adducts quantification}

DNA was extracted from T lymphocytes, digested to deoxynucleosides and then dissolved in $\mathrm{H}_{2} \mathrm{O} / \mathrm{CH}_{3} \mathrm{OH}$ 1/1 (v/v) prior to HPLC-MS/MS injection according to a protocol previously described [19].

\subsection{Comet assays}

The alkaline comet assay was used to detect strand breaks and alkali-labile sites as previously described [20]. T lymphocytes were embedded in $0.7 \%$ low melting point agarose and laid on CometAssay ${ }^{\circledR}$ HT Slide (Trevigen, Montlucon, France). Slides were then lysed (pH 10) for at least $1 \mathrm{~h}$ at $4{ }^{\circ} \mathrm{C}$. A parallel digestion with formamido pyrimidine glycosylase (FPG), allowing the detection of oxidative damage, was performed as already described [21]. Electrophoresis was processed for $24 \mathrm{~min}$ at a $\mathrm{pH}>13$. Fifty cells per deposit and two deposits per sample were analyzed. After staining with SYBR Gold Nucleic Acid Gel Stain, slides were observed at 20x magnification using a LEICA DMIRB video microscope. Images were acquired with a CoolSnapHQ Princeton instrument camera and analyzed with the ImageJ open source software using the OpenComet plugin (www.opencomet.org). The extent of DNA damage was evaluated for each cell through the measurement of intensity of all tail pixels divided by the total intensity of all pixels in head and tail of comet. The median from these 100 values was calculated, and named \% tail DNA.

\subsection{Caspase 3 activity measurement}

Caspase 3 activity was measured using its fluorogenic peptide substrate Asp-Glu-Asp--AMC. Briefly, proteins $(50 \mu \mathrm{g})$ from $\mathrm{T}$ lymphocytes lysates were incubated with $80 \mu \mathrm{M}$ substrate in buffer assay (20 mM Pipes, pH 7.2, $100 \mathrm{mM} \mathrm{NaCl,} 1 \mathrm{mM}$ EDTA, 0.1\% CHAPS, 10\% sucrose, and $10 \mathrm{mM}$ dithiothreitol). Caspase-mediated release of AMC was then monitored 
continuously over a 1-h period using an EnSpire Multimode 2300 Plate Reader (Perkin Elmer, Waltham, MA). Excitation and emission wavelengths were 380 and $460 \mathrm{~nm}$.

\subsection{Proliferation assay}

T-cell proliferation was measured by $\left[{ }^{3} \mathrm{H}\right]$-methyl-thymidine incorporation as previously described [15].

\subsection{Cell division assay by flow cytometry}

To determine cell division, T lymphocytes were labeled with $0.25 \mu \mathrm{M}$ CFSE and then treated with $\mathrm{B}[a] \mathrm{P}$. Cell division was next determined by analyzing CFSE dilution using a BD LSR Fortessa flow cytometer. Data are collected using FACSDiva software (BD Biosciences, San Jose, CA) and replicative index was calculated as the sum of the cells in all generations divided by the calculated number of original parent cells.

\subsection{Immunofluorescence}

$\mathrm{T}$ lymphocytes fixed on Polysine $\mathrm{TM}^{\mathrm{TM}}$ slides (Thermofisher Scientific) with $4 \%$ paraformaldehyde were stained with primary antibodies for $2 \mathrm{~h}$ and then incubated with secondary antibodies for $1 \mathrm{~h}$ as previously described [15]. For $\gamma$-H2AX, 53BP1 and RAD51 staining, a triton-extraction step was performed before fixation. Nuclei were counterstained with $0.5 \mu \mathrm{g} / \mathrm{mL}$ DAPI for $5 \mathrm{~min}$. Slides were viewed using an automated microscope Leica DMRXA2. Images were analyzed with the ImageJ open source software (www.imagej.nhi.gov). For phospho-ATM staining, each value represents the median fluorescence intensity of at least 50 nuclei evaluated. For $\gamma$-H2AX, 53BP1 and RAD51 staining, cells were scored positive for foci formation when $>5$ foci/nuclei were detected for at least 100 cells evaluated. 


\subsection{Mutagenesis frequency determination by the Pig A assay}

Ten days after treatment, T lymphocytes are stained on ice with an allophycocyanin-anti CD59 antibody (clone OV9A2, Thermofischer Scientific), combined with an inactive variant of the fluorescent proaerolysin protein (Tebu-Bio France, Le Perray-en-Yvelines, France) [22]. These two biomarkers are specific for the glycosylphosphatidylinositol-linked proteins. To determine the Pig A mutant frequency, T lymphocytes were analyzed by flow cytometry. Dead cells were excluded by DAPI staining, and cells doublets were discriminated and excluded by comparing Area and Height signals of Forward Scatter Parameters. Mutant frequencies were determined using a Miltenyi MACSQuant Analyzer flow cytometer (Miltenyi Biotech, Bergisch Gladbach, Germany) and calculated as the number of glycosylphosphatidylinositol-negative cells divided by the number of total live cells analyzed.

\subsection{Statistical analysis}

Data are expressed as mean \pm SEM. Statistical significance of the differences was assessed using GraphPad Instat (GraphPad software, INC., La Jolla, CA, USA) by paired Student's ttest, or analysis of variance followed by Dunnett or Student-Newman-Keuls post hoc tests. The criterion of significance was $\mathrm{p}<0.05$. 


\section{Results}

\subsection{B $[a] \mathrm{P}$ up-regulates CYP1 expression and activity in activated $\mathrm{T}$ lymphocytes.}

Many of the biological effects of PAHs are mediated through activation of AhR and the subsequent induction of CYP1-metabolizing enzymes [3]. We previously reported an early and functional up-regulation of the AhR by human $\mathrm{T}$ lymphocyte activation [15]. In the present study, we assayed the response to $\mathrm{B}[a] \mathrm{P}$ treatment in these $\mathrm{T}$ lymphocytes activated for 72 h. mRNA expression of two AhR target genes, CYP1A1 and 1B1, was first studied using RT-qPCR. As indicated in Fig. 1A and 1B, CYP1A1 and 1B1 mRNA levels were markedly increased in $\mathrm{B}[a] \mathrm{P}$-treated $\mathrm{T}$ lymphocytes when compared with their DMSO counterparts; a significant effect was detected for a treatment with $2 \mu \mathrm{M} \mathrm{B}[a] \mathrm{P}$ for the last 48 h of culture (Figure 1A). Such a 48-h treatment with $2 \mu \mathrm{M} \mathrm{B}[a] \mathrm{P}$ was also demonstrated to significantly over-expressed CYP1B1 protein as assessed by Western blotting; a more modest up-regulation of CYP1A1 was observed when compared with their DMSO counterparts (Fig. 1C). Next, to determine whether $\mathrm{B}[a] \mathrm{P}$ had an effect on catalytic activities of CYP1-enzymes, CYP1-related EROD activity was quantified in T lymphocytes treated with $2 \mu \mathrm{M} \mathrm{B}[a] \mathrm{P}$ for 8 , 24 and $48 \mathrm{~h}$ of culture. As indicated in Fig. 1D, B[a]P significantly increased CYP1-related EROD activity after a 48 h-treatment with $2 \mu \mathrm{M} \mathrm{B}[a] \mathrm{P}$.

\subsection{B $[a] P$ forms dG-N ${ }^{2}$-BPDE adducts and DNA DSBs in activated T lymphocytes.}

To determine whether the induction of CYP1 enzyme activity resulted in an increased bioactivation of $\mathrm{B}[a] \mathrm{P}$ to reactive metabolites, we quantified the level of $\mathrm{dG}-\mathrm{N}^{2}-\mathrm{BPDE}$ using HPLC-MS/MS approach subsequently to DNA extraction and digestion. As illustrated in Fig. $2 \mathrm{~A}$, the formation of $\mathrm{dG}-\mathrm{N}^{2}$-BPDE DNA adducts only occurred in $\mathrm{T}$ lymphocytes treated with $2 \mu \mathrm{M} \mathrm{B}[a] \mathrm{P}$ for $48 \mathrm{~h}$, corresponding to the significant induction of CYP1-related EROD activity (Fig. 1D). In addition, the CYP1 inhibitor $\alpha-\mathrm{NF}$ which markedly decreased $\mathrm{B}[a] \mathrm{P}-$ 
induced EROD activity (data not shown), significantly reduced the formation of $\mathrm{dG}-\mathrm{N}^{2}$ BPDE DNA adducts occurring in response to $\mathrm{B}[a] \mathrm{P}$ (Fig. 2B). This indicated that such a treatment allowed not only the expression of functional CYP1 activity but also the formation of $\mathrm{dG}-\mathrm{N}^{2}$-BPDE DNA adducts. We then evaluated whether such a $\mathrm{B}[a] \mathrm{P}$ activation was associated with DNA damage by using alkaline comet assays [23]. As shown in Fig. 3A, a 48 h-treatment of $\mathrm{T}$ lymphocytes with $2 \mu \mathrm{M}$ of $\mathrm{B}[a] \mathrm{P}$ significantly increased the $\%$ of tail DNA, indicating the presence of DNA damage. Interestingly, such effects were not due to apoptotic DNA fragmentation since treatment with $2 \mu \mathrm{M} \mathrm{B}[a] \mathrm{P}$ for $48 \mathrm{~h}$ was not accompanied by any detectable increase in apoptosis as tested by an activated caspase-3 assay (Fig. 3B). Additionally, when the comet assay was combined with FPG enzyme, which allows the detection of oxidative damage [21], no increasing effect of $\mathrm{B}[a] \mathrm{P}$ treatment was observed (Fig. 3C), whereas a significant increase in oxidative damage was detected after treatment with potassium bromate (Fig. 3D), as previously reported [24]. As for the $\mathrm{dG}-\mathrm{N}^{2}$-BPDE DNA adducts, $\alpha-\mathrm{NF}$ significantly reduced the induction of DNA damage due to $\mathrm{B}[a] \mathrm{P}$ (data not shown). Taken together, these results demonstrate that, once metabolized in $\mathrm{T}$ lymphocytes, $\mathrm{B}[a] \mathrm{P}$ generates BPDE-DNA adducts and subsequently DNA damage without inducing apoptosis.

To examine in more detail the nature of the DNA damage, we first studied the phosphorylation of $\mathrm{H} 2 \mathrm{AX}$ on Ser139, an $\mathrm{H} 2 \mathrm{~A}$ histone variant (called $\gamma$-H2AX once phosphorylated). $\gamma-\mathrm{H} 2 \mathrm{AX}$ is considered as an early event after the introduction of strand breaks, forming distinct foci close to these breaks, that has been suggested as a specific marker for DNA DSBs $[25,26]$. In the present study, the formation of $\gamma$-H2AX foci was analyzed by immunostaining after $\mathrm{B}[a] \mathrm{P}$ treatment for 8 and $48 \mathrm{~h}$, defining cells as positive if more than 5 foci/nuclei were detected (Fig. 4A). As shown in Fig. 4A, significant distinctive foci characteristic of DNA DSBs were detected after a 48-h treatment with B $[a] \mathrm{P}$. To further 
validate the nature of the damage induced upon $\mathrm{B}[a] \mathrm{P}$ treatment, we performed immunofluorescence staining to detect 53BP1 foci, a second marker of DNA DSBs $[25,26]$. Similarly, 53BP1-positive cells were significantly increased after $\mathrm{B}[a] \mathrm{P}$ treatment for $48 \mathrm{~h}$ with a co-localization between $\gamma-\mathrm{H} 2 \mathrm{AX}$ foci and 53BP1 foci (Fig. 4A). Interestingly, $\alpha-\mathrm{NF}$ significantly counteracted the DNA DSB response induced upon $\mathrm{B}[a] \mathrm{P}$ treatment for $48 \mathrm{~h}$, as shown by the significant decrease of both $\gamma-\mathrm{H} 2 \mathrm{AX}$ and 53BP1 foci (Fig. 4B and 4C).

\subsection{B $[a] P$ induces a DDR with ATM kinase activation thus inducing p53-dependent response and cell survival in activated $T$ lymphocytes.}

We next characterized DDR signalling pathways in T lymphocytes treated with $2 \mu \mathrm{M} \mathrm{B}[a] \mathrm{P}$ for $48 \mathrm{~h}$. Since ATM kinase plays a critical role in the cellular response to DSB formation $[25,26]$, we assessed its activation by examining levels of phosphorylated ATM at ser1981 (phospho-ATM) using Western blotting. As shown in Fig. 5A, we found that phospho-ATM was not only expressed in activated $\mathrm{T}$ lymphocytes as previously described [27], but it also significantly increased upon $\mathrm{B}[\mathrm{a}] \mathrm{P}$ treatment for $48 \mathrm{~h}$. We also revealed increased nuclear localization of phospho-ATM by immunofluorescence (Fig. 5B), as well as a slight, but significant, increased phosphorylation of its primary substrate checkpoint kinase CHK2 on Thr68 (Fig. 5A). A more pronounced, but not significant, increase in the phosphorylation on ser317 of the effector kinase CHK1 was also observed after $\mathrm{B}[a] \mathrm{P}$ treatment (Fig. 5A). To address in detail the role of $\mathrm{ATM}$ in the $\mathrm{DDR}, \mathrm{B}[a] \mathrm{P}$ treatment was conducted in the presence or absence of KU-55933, an inhibitor of ATM, and immunofluorescence staining to detect $\gamma$ $\mathrm{H} 2 \mathrm{AX}$ foci was performed as classically reported [28]. Immunostaining of $\gamma-\mathrm{H} 2 \mathrm{AX}$ foci indicated that KU-55933 completely abrogated the $\mathrm{B}[a] \mathrm{P}$-induced $\gamma-\mathrm{H} 2 \mathrm{AX}$ foci (Fig. 5C), thus confirming ATM activation by $\mathrm{B}[a] \mathrm{P}$-induced DSBs. Based on the current model for $\mathrm{p} 53$ 
activation upon DNA damage after ATM activation [29], the phosphorylation of p53 at ser15 was also investigated. As shown in Fig. 5D, a treatment with $2 \mu \mathrm{M} \mathrm{B}[a] \mathrm{P}$ for $48 \mathrm{~h}$ caused a marked but not significant increase in p53 phosphorylation. This increase was accompanied by significant elevations in mRNA expression of various pro-survival p53 downstream target genes such as the E3 ubiquitin protein-ligase mdm2 and the cycle-dependent kinase inhibitor 1A CDKN1A, after a 48-h treatment with $\mathrm{B}[a] \mathrm{P}$; gadd45A mRNA expression was also increased but failed to reach a significant level (Fig. 5E). Since KU-55933 is able to counteract both $\mathrm{B}[a] \mathrm{P}$-induced $\mathrm{p} 53$ phosphorylation and its transcriptional transactivation (Fig. 5E inset), this p53 activation also appears ATM-dependent.

Consistent with the CDKN1A mRNA up-regulation, protein levels for p21 were significantly increased after treatment with $2 \mu \mathrm{M} \mathrm{B}[a] \mathrm{P}$ for $48 \mathrm{~h}$ (Fig. 6A), prompting us to analyse the effect of $\mathrm{B}[a] \mathrm{P}$ on DNA replication [30]. As shown in Fig. 6B, incorporation of $\left[{ }^{3} \mathrm{H}\right]$-methyl-thymidine monitored during the last $18 \mathrm{~h}$ of culture indicated a significantly decrease in replicative DNA synthesis in $\mathrm{B}[a] \mathrm{P}$-treated $\mathrm{T}$ lymphocytes for $48 \mathrm{~h}$. Parallel experiments using CFSE dilution demonstrated that such treatment significantly increased the $\%$ of non-dividing lymphocytes and decreased, without reaching a significant level, the $\%$ of lymphocytes with three or more divisions (Fig. 6C). A slight, but not statistically significant, increase in $\mathrm{G} 2 / \mathrm{M}$ phase was also found after 48-h treatment with $\mathrm{B}[a] \mathrm{P}$ (data not shown). Interestingly, there was no evidence of apoptosis at $48 \mathrm{~h}$ after treatment with $2 \mu \mathrm{M} \mathrm{B}[a] \mathrm{P}$ as indicated by caspase 3 assay (Fig. 3B) and mRNA levels of apoptosis-regulating genes such as BBC3 and PMAIP1 (Fig. 5E). 


\section{4. $\mathrm{B}[a] \mathrm{P}$ induces DSB repair pathways but leads to gene mutations in activated $\mathrm{T}$}

\section{lymphocytes.}

The well-documented link between DNA replication delay and activation of repair machinery [31] prompted us to examine the cellular repair of $\mathrm{B}[a] \mathrm{P}$-damaged $\mathrm{DNA}$. We have first profiled a panel of 84 DNA repair genes using the $\mathrm{RT}^{2}$ Profiler $^{\mathrm{TM}} \mathrm{PCR}$ array on pools of RNAs isolated from DMSO or $\mathrm{B}[a] \mathrm{P}$-treated cultures of $\mathrm{T}$ lymphocytes established from 9 different blood donors. After a 24-h B[a]P treatment, we found 14 genes whose expression was shown to be regulated considering a cut-off of 1.5-fold (Fig. 7A). Among these genes, five were associated with the nucleotide excision pathway, i.e. those encoding the DNA repair excision proteins ERCC6, ERCC4, ERCC3 and RAD23B, and the STE20 like kinase SLK. Five genes belong to the DSB repair functional group such as the breast cancer genes 1 and 2 BRCA1 and BRCA2, the DSB repair nuclease MRE11A and the BRCA1-interacting protein 1 BRIP1 for Homologous recombination (HR) and the X-ray repair cross complementing 5 XRCC5 for the non-homologous end-joining DNA repair system. To characterize repair events by homologous recombination previously reported to be involved in DSB repair [32], we next performed immunofluorescence staining to detect the recruitment of RAD51, a crucial recombinase protein involved in $\mathrm{HR}$ after treatment with $2 \mu \mathrm{M} \mathrm{B}[a] \mathrm{P}$ for 48 h. As shown in Fig. 7B, the number of RAD51-positive cells significantly increased after $\mathrm{B}[a] \mathrm{P}$ treatment with a co-localization between $\gamma$-H2AX foci and RAD51 foci (Fig. 7B), thus revealing the HR machinery mobilization.

Ten days after $\mathrm{B}[a] \mathrm{P}$ treatment for $48 \mathrm{~h}$, T lymphocytes were isolated for Pig A mutagenesis analysis. As shown in Fig. 7C and despite an important inter-individual differences in $\mathrm{B}[a] \mathrm{P}$ response, the Pig A mutant frequency was significantly increased in $\mathrm{B}[a] \mathrm{P}$-treated lymphocytes when compared with their DMSO counterparts. 


\section{Discussion}

PAHs are ubiquitous environmental contaminants exerting various toxic effects, mainly associated with AhR activation and the subsequent induction of CYP1-metabolizing enzymes [3]. Although several studies suggested a possible link between exposure to PAHs and the risk of $\mathrm{T}$ cell lymphoma [8], their exact role to the development of lymphoma remains unclear. Recently, we have reported an up-regulation of the AhR by the physiologically relevant T-cell stimulation approach by anti-CD3 and anti-CD28 antibodies in primary human lymphocytes [15]. Interestingly, this up-regulation had functional consequences such as the induction of CYP1 expression and activity [15,33], thus suggesting their increased ability to metabolize AhR ligands and to produce consequent DNA damage. The aim of the present study was to characterize the genotoxic response produced by the prototypical $\mathrm{PAH} \mathrm{B}[a] \mathrm{P}$, and to study the DDR elicited in these CD3/CD28-activated primary human T lymphocytes.

We have first reported that, following a 24-h CD3/CD28-mediated T lymphocyte activation inducing an $\mathrm{AhR}$ functional activation [15], a 48-h treatment with $2 \mu \mathrm{M} \mathrm{B}[a] \mathrm{P}$ increases both mRNA and protein expression of CYP1A1 and 1B1, associated with an increased CYP1 catalytic activation. This $\mathrm{B}[a] \mathrm{P}$-induced CYP1 activity leads to the formation of highly reactive metabolites as detected by quantifying dG-N ${ }^{2}$-BPDE DNA adducts. dG-N ${ }^{2}$ BPDE DNA adducts have been already described in phytohemagglutinin-activated $\mathrm{T}$ lymphocytes but following a direct treatment with BPDE reactive metabolite [34]. Here, we demonstrated the sufficient ability of activated $\mathrm{T}$ lymphocytes to bioactivate and convert $\mathrm{B}[a] \mathrm{P}$ into reactive metabolites after a 48 -h treatment, mainly via its effects on CYP1 expression and activity as shown by using the CYP1 inhibitor $\alpha$-NF. Despite the more inducible CYP1A1 mRNA expression as previously reported in cultured human lymphocytes treated with AhR ligands [35] and because the levels of CYP1B1 protein increased greatly upon $\mathrm{B}[a] \mathrm{P}$ treatment in activated $\mathrm{T}$ lymphocytes, the bioactivation of $\mathrm{B}[a] \mathrm{P}$ proceeded 
probably via CYP1B1 induction in agreement with a very recent study [36]. CYP1B1 has been already reported to play a prominent part in the metabolic activation and genotoxic effects of PAHs [37] and in Ah-related lymphomas [38]. By using the comet assay, we observed that $48 \mathrm{~h}$ after $\mathrm{B}[\mathrm{a}] \mathrm{P}$ treatment, $\mathrm{T}$ lymphocytes also exhibited significant amounts of DNA damage, also relying upon metabolic activation of $\mathrm{B}[a] \mathrm{P}$. Because reactive oxygen species could be produced by CYP activity and that DNA damage could be biomarkers of oxidative stress, we used the FPG-modified alkaline comet assay to detect oxidative damage. No induction of oxidative DNA damage was observed upon $\mathrm{B}[a] \mathrm{P}$ treatment as reported by Genies et al. [39]. Indeed, whereas they showed significant levels of oxidative lesions upon treatment with $2 \mu \mathrm{M} \mathrm{B}[a] \mathrm{P}$ in different human cell lines, they concluded that the frequency of oxidative lesions was much lower than the frequency of BPDE adducts representing only a minor contribution to the genotoxicity of $\mathrm{B}[a] \mathrm{P}[39]$. A thorough characterization of the DNA damage produced by $\mathrm{B}[a] \mathrm{P}$ revealed the generation of DNA DSBs using $\gamma-\mathrm{H} 2 \mathrm{AX}$ staining. Although the phosphorylation of $\mathrm{H} 2 \mathrm{AX}$ into $\gamma-\mathrm{H} 2 \mathrm{AX}$ is considered as a hallmark of the number of DSBs generated, it has also been reported to be activated by other stresses such as chromatin structure changes [25,26]. Using 53BP1, an additional marker of DSBs $[25,26]$, and as indicated by its co-localization with $\gamma-\mathrm{H} 2 \mathrm{AX}$, we confirmed that $\mathrm{B}[a] \mathrm{P}$ induces true DNA DSBs in activated T lymphocytes. Additionally, a 48-h treatment with $\mathrm{B}[a] \mathrm{P}$ triggered ATM-CHK2 checkpoint pathway activation, compatible with a DSB-type response [25,26].

In contrast to its genotoxic effects, $\mathrm{B}[a] \mathrm{P}$ did not alter cell viability by inducing apoptosis in activated $\mathrm{T}$ lymphocytes after a 48 -h treatment with $2 \mu \mathrm{M}$. This concentration of $\mathrm{B}[a] \mathrm{P}$ has been already reported to have a limited impact on viability in different human cell lines [39]. It could be explained by an efficient DDR, a well-co-ordinated network of signalling cascade occurring upon DNA damage [40]. In primary activated T lymphocytes, it is reasonable to hypothesize that p53 is central in this situation given the roles of p53 target 
genes in survival and death [41]. We found that $\mathrm{B}[a] \mathrm{P}$ induces the accumulation and the phosphorylation of p53, as well as the induction of its transcriptional targets. Among p53responsive genes, we reported preferential up-regulation of pro-survival genes such as its negative regulator $\mathrm{mdm} 2$, the cell cycle and DNA damage regulators gadd $45 \mathrm{~A}$ and CDKN1A, thereby affecting the survival-death balance. A marked increase in the corresponding protein $\mathrm{p} 21$ encoded by CDKN1A gene was associated, probably conferring increased $\mathrm{T}$ lymphocyte survival towards $\mathrm{B}[a] \mathrm{P}$ treatment, as previously reported in human diploid lung fibroblasts treated with $\mathrm{B}[a] \mathrm{P}[42]$. This survival response was accompanied by a decrease in DNA synthesis and in cellular division. However, although strong induction of p21 occurred, only marginal changes in the cell cycle distribution (i.e., a slightly enhanced fraction within the $\mathrm{G} 2 / \mathrm{M}$ phases (data not shown)) were observed $48 \mathrm{~h}$ following $\mathrm{B}[a] \mathrm{P}$ treatment. These data are consistent with recent studies in human fibroblasts treated with BPDE showing a slow-down of replication without any pronounced cell cycle arrest to protect against cell death [43]. These data are in agreement with ours showing that $\mathrm{B}[a] \mathrm{P}$ failed to induce T lymphocyte apoptosis over a treatment of $48 \mathrm{~h}$ as evidenced by the absence of significant changes in caspase activity. Combined with other studies reporting that CHK1 protects cells from apoptosis [44,45], activation of the ATM-CHK1 pathway might be sufficient to prevent $\mathrm{T}$ lymphocyte death and contribute to survival following $\mathrm{B}[a] \mathrm{P}$-induced DSBs. Cell survival may be also correlated with an increase in the efficiency of DNA repair mechanisms as reported for $\mathrm{B}[a] \mathrm{P}$ with nucleotide excision repair removing DNA adducts or with translesion DNA synthesis which enable cells to tolerate DNA damage [46]. Thereby, in addition to the changes detected in mRNA levels of genes involved in excision repair, the mRNA expression levels of HR factors (MRE11A, BRCA1, BRIP1 and BRCA2) increased in response to $\mathrm{B}[a] \mathrm{P}$, and the recombinase $\mathrm{RAD} 51$ protein is recruited to $\mathrm{B}[a] \mathrm{P}$-induced $\mathrm{DSBs}$ demonstrating the role of $\mathrm{HR}$ in response to $\mathrm{B}[a] \mathrm{P}$. In the present study, we cannot exclude 
that part of the generated DSBs upon $\mathrm{B}[a] \mathrm{P}$ treatment are repaired by the error-prone nonhomologous end-joining pathway. We propose then a mechanism by which activated $\mathrm{T}$ lymphocytes repair $\mathrm{B}[a] \mathrm{P}$-induced $\mathrm{DSBs}$ thus allowing their survival but placing them at greater risk to accumulate mutations, as suggested for some B-lymphocyte tumours [47]. By using the Pig A mutagenesis assay, we reported that $\mathrm{B}[a] \mathrm{P}$ treatment resulted in an increased gene mutation frequency in activated T lymphocytes treated with $2 \mu \mathrm{M} \mathrm{B}[a] \mathrm{P}$ for $48 \mathrm{~h}$. The mutagenic activity of $\mathrm{B}[a] \mathrm{P}$ has been extensively studied in humans using both in vivo and in vitro approaches [6]. Most of the in vitro studies of DNA damage and mutations due to PAHs have been performed using human transformed cell lines, opening the question of the relevance of the data obtained in these studies to human normal cells and tissues. Consequently, the use of primary human T lymphocytes, which are normal non-transformed human cells, may be more adequate to better characterize the response of normal human cells to PAHs. Finally, the relevance of the physiological activation of human T lymphocytes, triggering an efficient mobilization of $\mathrm{AhR}$ [15], is of great interest towards exposure to PAHs. Indeed, one may speculate that exposure to these carcinogenic contaminants, may contribute to exacerbated DNA alterations during an immune response. Altogether, these data indicate that primary activated human $\mathrm{T}$ lymphocytes appear to be a major cell type targeted by PAHs reinforcing thus the link suggested between PAH exposure and risk of T lymphoma [8]

In conclusion, the present study demonstrates the metabolic efficiency of primary human activated $\mathrm{T}$ lymphocytes towards contaminants such as $\mathrm{B}[a] \mathrm{P}$ to form specific DNA damage and increase mutation frequency, proposing them as a good model to analyse human health issues depending on the environment. 


\section{Acknowledgements}

This work was supported by The French National Research Program for Environmental and Occupational Health of ANSES with the support of the Cancer TMOI of the French National Alliance for Life and Health Sciences (AVIESAN) (2014/1/052). Marie Liamin is a recipient of ANSES. The authors acknowledge the assistance provided by Marianne Chevalier for comet assays, Serge Boiteux for kindly providing FPG and Dominique Lagadic-Gossmann for critical reading of the manuscript. LC-MS analyses were achieved in the MetaToulAXIOM platform, which is part of the French national infrastructure for metabolomics and fluxomics: MetaboHUB (MetaboHUB-ANR-11-INBS-0010). The authors are also grateful to the MRic Photonics and to the flow cytometry platforms of Biosit, Universite de Rennes 1 (France).

Conflict of interest: The authors declare that they have no conflict of interest.

\section{Figure legends}

Fig. 1: Induction of CYP1 expression and activity in response to $B[a] P$ treatment in activated human $\mathbf{T}$ lymphocytes. $\mathrm{T}$ lymphocytes activated for $72 \mathrm{~h}$ were treated with vehicle (DMSO) or with various increasing $\mathrm{B}[a] \mathrm{P}$ concentrations for the last $48 \mathrm{~h}$ of culture (A) and with $2 \mu \mathrm{M} \mathrm{B}[a] \mathrm{P}$ for various lengths of time (B, C, D). (A, B) CYP1A1 and CYP1B1 mRNA expression was analyzed using RT-qPCR. (C) CYP1A1 and CYP1B1 protein expression was analyzed by Western blotting. A representative blot is displayed on the upper panel. (D) Catalytic activity of CYP1 enzymes was evaluated by EROD assay. (A, B, C, D) Data are expressed relative to mRNA expression level (A, B), protein expression level (C) 
and EROD activity (D) in DMSO-treated T lymphocytes, arbitrarily set at 1 unit, and are shown as mean \pm SEM of four (D), five $(A, C)$ and six (B) independent experiments performed with $\mathrm{T}$ lymphocytes from different blood donors with triplicate per experiment (A, B, D). ${ }^{*} p<0.05$ when compared with DMSO-treated $\mathrm{T}$ lymphocytes (analysis of variance followed by the Dunnett's multirange test (A, B, D) and paired Student's $t$ test (C)).

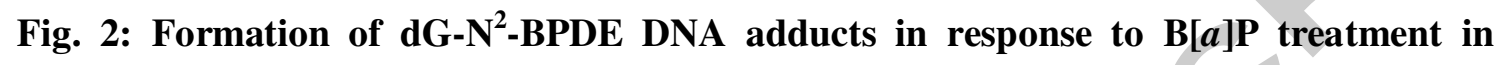
activated human $\mathbf{T}$ lymphocytes. $\mathrm{T}$ lymphocytes activated for $72 \mathrm{~h}$ were treated with vehicle (DMSO) or with $2 \mu \mathrm{M} \mathrm{B}[a] \mathrm{P}$ for the last 8 and $48 \mathrm{~h}$ of culture (A) and pre-treated or not with $2 \mu \mathrm{M} \alpha$-naphthoflavone $(\alpha-\mathrm{NF})$ before $\mathrm{B}[a] \mathrm{P}$ treatment for the last $48 \mathrm{~h}$ of culture (B). dG-N ${ }^{2}$-BPDE DNA adducts were quantified using HPLC/MS-MS approach. Data are expressed as dG- $\mathrm{N}^{2}$-BPDE DNA adducts for $10^{6}$ nucleosides, and are shown as mean \pm SEM of eight (A) and five (B) independent experiments performed with $\mathrm{T}$ lymphocytes from different blood donors. ${ }^{*} p<0.05$ when compared with $\alpha$-NF-untreated T lymphocytes (paired Student's $t$ test).

\section{Fig. 3: Induction of DNA damage in response to $\mathrm{B}[a] \mathrm{P}$ treatment in activated human $\mathrm{T}$}

lymphocytes. T lymphocytes activated for $72 \mathrm{~h}$ were treated with vehicle (DMSO) or with 2 $\mu \mathrm{M} \mathrm{B}[a] \mathrm{P}$ for the last $8(\mathrm{~A})$ and $48 \mathrm{~h}$ of culture $(\mathrm{A}, \mathrm{B}, \mathrm{C})$ and with $3 \mathrm{mM}$ potassium bromate for the last $2 \mathrm{~h}$ of culture (D). (A, C, D) DNA damage was analyzed using alkaline comet assay (A) and FPG-modified alkaline comet assay (C, D). Data are expressed as \% tail DNA and are shown as mean \pm SEM of six $(A)$ and eight $(C, D)$ independent experiments performed with $\mathrm{T}$ lymphocytes from different blood donors with duplicate per experiment. (B) Apoptotic effects were assayed by measuring caspase-3 activity. Data are expressed relative to the caspase-3 activity in DMSO-treated T lymphocytes, arbitrarily set at 1 unit, and 
are shown as mean \pm SEM of seven independent experiments performed with $\mathrm{T}$ lymphocytes from different blood donors with duplicate per experiment. $* p<0.05$ when compared with DMSO-treated T lymphocytes (analysis of variance followed by the Dunnett's multirange test (A)) and with potassium bromate-treated T lymphocytes in absence of FPG (analysis of variance followed by the Student-Newman-Keuls's multirange test (D)).

Fig. 4: Induction of DNA DSBs in response to $B[a] P$ treatment in activated human $T$ lymphocytes. T lymphocytes activated for $72 \mathrm{~h}$ were treated with vehicle (DMSO) or with 2 $\mu \mathrm{M} \mathrm{B}[a] \mathrm{P}$ for the last 8 (A) and $48 \mathrm{~h}$ of culture (A, B, C) and pre-treated or not with $2 \mu \mathrm{M} \alpha-$ naphthoflavone $(\alpha-N F)$ before $\mathrm{B}[a] \mathrm{P}$ treatment for the last $48 \mathrm{~h}$ of culture $(\mathrm{B}, \mathrm{C})$. DNA DSBs were detected by $\gamma-\mathrm{H} 2 \mathrm{AX}$ and 53BP1 immunostaining and analyzed by fluorescence microscopy (magnification x63). (A) Representative photographs of co-localization of $\gamma$ $\mathrm{H} 2 \mathrm{AX}$ and 53BP1 are displayed on the left panel. Data are expressed as $\%$ of T lymphocytes positive for $\gamma$-H2AX $(\mathrm{A}, \mathrm{B})$ and 53BP1 $(\mathrm{A}, \mathrm{C})$ foci formation when $>5$ foci/nuclei were quantified and are shown as mean \pm SEM of four (A) and five $(B, C)$ independent experiments performed with $\mathrm{T}$ lymphocytes from different blood donors. ${ }^{*} p<0.05$ when compared with DMSO-treated T lymphocytes (A) and with $\alpha$-NF-untreated T lymphocytes (B, C) (paired Student's $t$ tests).

Fig. 5: Induction of a DDR with ATM kinase activation increasing p53 activity in response to $\mathrm{B}[a] P$ treatment in activated human $\mathrm{T}$ lymphocytes. $\mathrm{T}$ lymphocytes activated for $72 \mathrm{~h}$ were treated with vehicle (DMSO) or with $2 \mu \mathrm{M} \mathrm{B}[a] \mathrm{P}$ for the last $48 \mathrm{~h}$ of culture (A, B, D, E) and pre-treated or not with $10 \mu \mathrm{M}$ KU-55933 before $\mathrm{B}[a] \mathrm{P}$ treatment for the last $48 \mathrm{~h}$ of culture $(\mathrm{C}, \mathrm{E})$. (A, D) Expression of the phosphorylated forms of ATM (phospho- 
ATM), CHK1 (phospho-CHK1) and CHK2 (phospho-CHK2) (A) and of p53 (phospho-p53) and total p53 (p53) proteins (D) was analyzed by Western blotting. Representative blots are displayed on the upper panel. (B) Activation of ATM was detected by nuclear phospho-ATM immunostaining and analyzed by fluorescence microscopy (magnification x63). Data are expressed relative to protein expression level (A, D) and to nuclear phospho-ATM fluorescence intensity (B) in DMSO-treated T lymphocytes, arbitrarily set at 1 unit, and are shown as mean \pm SEM of four (A, phospho-ATM), five (A, phospho-CHK1 and phosphoCHK2, D) and eight (B) independent experiments performed with T lymphocytes from different blood donors. (C) DNA DSBs were detected by $\gamma-\mathrm{H} 2 \mathrm{AX}$ immunostaining and analyzed by fluorescence microscopy (magnification x63). Data are expressed as \% of $\mathrm{T}$ lymphocytes positive for $\gamma-\mathrm{H} 2 \mathrm{AX}$ foci formation when $>5$ foci/nuclei were quantified and are shown as mean \pm SEM of six samples pooled from independent experiments performed with T lymphocytes from different blood donors. (E) mRNA expression of pro-apoptotic and pro-survival p53 target genes was analyzed using RT-qPCR. Data are expressed relative to mRNA expression level in DMSO-treated T lymphocytes, arbitrarily set at 1 unit, and are shown as mean \pm SEM of seven independent experiments performed with $\mathrm{T}$ lymphocytes from different blood donors with triplicate per experiment. The inhibition by KU-55933 of $\mathrm{B}[a] \mathrm{P}$-induced $\mathrm{p} 53$ phosphorylation and of the subsequent induction of its transcriptional target gene CDKN1A by Western blotting and RT-qPCR analysis respectively are displayed in the inset. ${ }^{*} p<0.05$ when compared with DMSO-treated T lymphocytes (A, E) and with KU-55933-untreated T lymphocytes (C) (paired Student's $t$ tests).

Fig. 6: Induction of p21 expression, alteration of DNA synthesis and cellular division in response to $\mathrm{B}[\boldsymbol{a}] \mathrm{P}$ treatment in activated human $\mathrm{T}$ lymphocytes. $\mathrm{T}$ lymphocytes activated for $72 \mathrm{~h}$ were treated with vehicle (DMSO) or with $2 \mu \mathrm{M} \mathrm{B}[a] \mathrm{P}$ for the last $48 \mathrm{~h}$ of culture. 
(A) Expression of p21 protein was analyzed by Western blotting. A representative blot is displayed on the upper panel. Data are expressed relative to protein expression level in DMSO-treated T lymphocytes, arbitrarily set at 1 unit, and are shown as mean \pm SEM of six independent experiments performed with $\mathrm{T}$ lymphocytes from different blood donors. (B) $\left[{ }^{3} \mathrm{H}\right]$-methyl-thymidine incorporation into DNA was determined during the last $18 \mathrm{~h}$ of culture. Data are expressed relative to the $\left[{ }^{3} \mathrm{H}\right]$-methyl-thymidine incorporation in DMSOtreated $\mathrm{T}$ lymphocytes, arbitrarily set at 1 unit, and are shown as mean \pm SEM of eight independent experiments performed with $\mathrm{T}$ lymphocytes from different blood donors with triplicate per experiment. (C) Cell division was analyzed by flow cytometry using CFSE dilution. Representative graphs saved during flow cytometry analysis are displayed on the left panel. Data are expressed as \% of parental cells and are shown as mean \pm SEM of five independent experiments performed with $\mathrm{T}$ lymphocytes from different blood donors with duplicate per experiment. ${ }^{*} p<0.05$ when compared with DMSO-treated T lymphocytes (paired Student's $t$ test (A, B) and analysis of variance followed by the Student-NewmanKeuls's multirange test $(\mathrm{C})$ ).

\section{Fig. 7: Recruitment of RAD51 to DNA DSBs and Pig A mutation frequency in response} to $\mathbf{B}[\boldsymbol{a}] \mathbf{P}$ treatment in activated human $\mathbf{T}$ lymphocytes. $T$ lymphocytes activated for $72 \mathrm{~h}$ were treated with vehicle (DMSO) or with $2 \mu \mathrm{M} \mathrm{B}[a] \mathrm{P}$ for the last $24 \mathrm{~h}(\mathrm{~A})$ and $48 \mathrm{~h}$ of culture $(\mathrm{B}, \mathrm{C})$. (A) Top regulated DNA repair genes were detected by expression profiling analysis using the $\mathrm{RT}^{2}$ Profiler ${ }^{\mathrm{TM}} \mathrm{PCR}$ array and selected on the basis of a 1.5 -fold change factor of mRNA expression in response to $\mathrm{B}[a] \mathrm{P}$. Data are expressed relative to $\mathrm{mRNA}$ expression level in DMSO-treated T lymphocytes, arbitrarily set at 1 unit, and are from one experiment performed on pools of RNAs isolated from cultures of T lymphocytes established from 9 blood donors. (B) Recruitment of RAD51 to DNA DSBs was detected by $\gamma-\mathrm{H} 2 \mathrm{AX}$ and 
RAD51 immunostaining and analyzed by fluorescence microscopy (magnification x63).

Representative photographs of co-localization of $\gamma$-H2AX and RAD51 are displayed on the left panel. Data are expressed as \% of $\mathrm{T}$ lymphocytes positive for RAD51 foci formation when $>5$ foci/nuclei were quantified and are shown as mean \pm SEM of four independent experiments performed with $\mathrm{T}$ lymphocytes from different blood donors. (C) After a 48-h treatment with $\mathrm{B}[a] \mathrm{P}, \mathrm{T}$ lymphocytes were maintained in a proliferation media for ten days and then analyzed for the Pig A mutation frequency. Data are shown as mean \pm SEM of eight independent experiments performed with $\mathrm{T}$ lymphocytes from different blood donors. ${ }^{*} p<$ 0.05 when compared with DMSO-treated T lymphocytes (paired Student's $t$ test $(\mathrm{B}, \mathrm{C})$ ).

\section{References}

[1] H.A. Hattemer-Frey, C.C. Travis, Benzo-a-pyrene: environmental partitioning and human exposure, Toxicol. Ind. Health. 7 (1991) 141-157.

[2] M. Sørensen, H. Autrup, O. Hertel, H. Wallin, L.E. Knudsen, S. Loft, Personal exposure to PM2.5 and biomarkers of DNA damage, Cancer Epidemiol. Biomark. Prev. Publ. Am. Assoc. Cancer Res. Cosponsored Am. Soc. Prev. Oncol. 12 (2003) 191-196.

[3] T. Shimada, Xenobiotic-metabolizing enzymes involved in activation and detoxification of carcinogenic polycyclic aromatic hydrocarbons, Drug Metab. Pharmacokinet. 21 (2006) 257-276.

[4] K. Peltonen, A. Dipple, Polycyclic aromatic hydrocarbons: chemistry of DNA adduct formation, J. Occup. Environ. Med. Am. Coll. Occup. Environ. Med. 37 (1995) 52-58.

[5] B. Moorthy, C. Chu, D.J. Carlin, Polycyclic aromatic hydrocarbons: from metabolism to lung cancer, Toxicol. Sci. Off. J. Soc. Toxicol. 145 (2015) 5-15.

[6] IARC Working Group on the Evaluation of Carcinogenic Risks to Humans, Some nonheterocyclic polycyclic aromatic hydrocarbons and some related exposures, IARC Monogr. Eval. Carcinog. Risks Hum. 92 (2010) 1-853.

[7] E.D. Kroese, P.M. Dortant, H. van Steeg, C.T. van Oostrom, C.W. van der Houven van Oordt, H.J. van Kranen, A. de Vries, P.W. Wester, C.F. van Kreijl, Use of E mu-PIM-1 transgenic mice short-term in vivo carcinogenicity testing: lymphoma induction by benzo[a]pyrene, but not by TPA, Carcinogenesis. 18 (1997) 975-980.

[8] C.T. DellaValle, N.C. Deziel, R.R. Jones, J.S. Colt, A.J.D. Roos, J.R. Cerhan, W. Cozen, R.K. Severson, A.R. Flory, L.M. Morton, M.H. Ward, Polycyclic aromatic hydrocarbons: determinants of residential carpet dust levels and risk of non-Hodgkin lymphoma, Cancer Causes Control. 27 (2016) 1-13. 
[9] P. Okano, H.N. Miller, R.C. Robinson, H.V. Gelboin, Comparison of benzo(a)pyrene and (-)-trans-7,8-dihydroxy-7,8-dihydrobenzo(a)pyrene metabolism in human blood monocytes and lymphocytes, Cancer Res. 39 (1979) 3184-3193.

[10] R.C. Gupta, K. Earley, F.F. Becker, Analysis of DNA adducts in putative premalignant hepatic nodules and nontarget tissues of rats during 2-acetylaminofluorene carcinogenesis, Cancer Res. 48 (1988) 5270-5274.

[11] D. Li, M. Wang, L. Cheng, M.R. Spitz, W.N. Hittelman, Q. Wei, In vitro induction of benzo(a)pyrene diol epoxide-DNA adducts in peripheral lymphocytes as a susceptibility marker for human lung cancer, Cancer Res. 56 (1996) 3638-3641.

[12] O. Pelkonen, K. Vähäkangas, D.W. Nebert, Binding of polycyclic aromatic hydrocarbons to DNA: comparison with mutagenesis and tumorigenesis, J. Toxicol. Environ. Health. 6 (1980) 1009-1020. [13] C.L. Thompson, Z. McCoy, J.M. Lambert, M.J. Andries, G.W. Lucier, Relationships among benzo(a)pyrene metabolism, benzo(a)pyrene-diol-epoxide:DNA adduct formation, and sister chromatid exchanges in human lymphocytes from smokers and nonsmokers, Cancer Res. 49 (1989) 6503-6511.

[14] A. Trickett, Y.L. Kwan, T cell stimulation and expansion using anti-CD3/CD28 beads, J. Immunol. Methods. 275 (2003) 251-255.

[15] L. Prigent, M. Robineau, S. Jouneau, C. Morzadec, L. Louarn, L. Vernhet, O. Fardel, L. Sparfel, The aryl hydrocarbon receptor is functionally upregulated early in the course of human T-cell activation, Eur. J. Immunol. 44 (2014) 1330-1340.

[16] C.M. Kendziorski, Y. Zhang, H. Lan, A.D. Attie, The efficiency of pooling mRNA in microarray experiments, Biostat. Oxf. Engl. 4 (2003) 465-477.

[17] L. Sparfel, M.-L. Pinel-Marie, M. Boize, S. Koscielny, S. Desmots, A. Pery, O. Fardel, Transcriptional signature of human macrophages exposed to the environmental contaminant benzo(a)pyrene, Toxicol. Sci. Off. J. Soc. Toxicol. 114 (2010) 247-259.

[18] T. Shimada, H. Yamazaki, M. Foroozesh, N.E. Hopkins, W.L. Alworth, F.P. Guengerich, Selectivity of polycyclic inhibitors for human cytochrome P450s 1A1, 1A2, and 1B1, Chem. Res. Toxicol. 11 (1998) 1048-1056.

[19] E.L. Jamin, A. Riu, T. Douki, L. Debrauwer, J.-P. Cravedi, D. Zalko, M. Audebert, Combined genotoxic effects of a polycyclic aromatic hydrocarbon (B(a)P) and an heterocyclic amine (PhIP) in relation to colorectal carcinogenesis, PloS One. 8 (2013) e58591.

[20] P. Lebailly, G. Mirey, F. Herin, Y. Lecluse, B. Salles, E. Boutet-Robinet, DNA damage in $\mathrm{B}$ and $\mathrm{T}$ lymphocytes of farmers during one pesticide spraying season, Int. Arch. Occup. Enyiron. Health. 88 (2015) 963-972.

[21] A. Azqueta, L. Arbillaga, A. López de Cerain, A. Collins, Enhancing the sensitivity of the comet assay as a genotoxicity test, by combining it with bacterial repair enzyme FPG, Mutagenesis. 28 (2013) 271-277.

[22] Y. Cao, L. Yang, N. Feng, O. Shi, J. Xi, X. You, C. Yin, H. Yang, K. Horibata, M. Honma, B. Qian, W. Weng, Y. Luan, A population study using the human erythrocyte PIG-A assay, Environ. Mol. Mutagen. 57 (2016) 605-614.

[23] A.R. Collins, A.A. Oscoz, G. Brunborg, I. Gaivão, L. Giovannelli, M. Kruszewski, C.C. Smith, R. Stetina, The comet assay: topical issues, Mutagenesis. 23 (2008) 143-151.

[24] J. Bausinger, G. Speit, Induction and repair of DNA damage measured by the comet assay in human T lymphocytes separated by immunomagnetic cell sorting, Mutat. Res. 769 (2014) 42-48.

[25] A. Kinner, W. Wu, C. Staudt, G. Iliakis, Gamma-H2AX in recognition and signaling of DNA double-strand breaks in the context of chromatin, Nucleic Acids Res. 36 (2008) 5678-5694. [26]D.R. Pilch, O.A. Sedelnikova, C. Redon, A. Celeste, A. Nussenzweig, 
W.M. Bonner, Characteristics of gamma-H2AX foci at DNA double-strand breaks sites, Biochem. Cell Biol. Biochim. Biol. Cell. 81 (2003) 123-129.

[27] T. Tanaka, M. Kajstura, H.D. Halicka, F. Traganos, Z. Darzynkiewicz, Constitutive histone H2AX phosphorylation and ATM activation are strongly amplified during mitogenic stimulation of lymphocytes, Cell Prolif. 40 (2007) 1-13.

[28] I. Hickson, Y. Zhao, C.J. Richardson, S.J. Green, N.M.B. Martin, A.I. Orr, P.M. Reaper, S.P. Jackson, N.J. Curtin, G.C.M. Smith, Identification and characterization of a novel and specific inhibitor of the ataxia-telangiectasia mutated kinase ATM, Cancer Res. 64 (2004) 9152-9159.

[29] E. Oya, J. Ovrevik, V.M. Arlt, E. Nagy, D.H. Phillips, J.A. Holme, DNA damage and DNA damage response in human bronchial epithelial BEAS-2B cells following exposure to 2-nitrobenzanthrone and 3-nitrobenzanthrone: role in apoptosis, Mutagenesis. 26 (2011) 697-708.

[30] T. Abbas, A. Dutta, p21 in cancer: intricate networks and multiple activities, Nat. Rev. Cancer. 9 (2009) 400-414.

[31] J.H. Houtgraaf, J. Versmissen, W.J. van der Giessen, A concise review of DNA damage checkpoints and repair in mammalian cells, Cardiovasc. Revasc. Med. 7 (2006) 165172.

[32] A. Beucher, J. Birraux, L. Tchouandong, O. Barton, A. Shibata, S. Conrad, A.A. Goodarzi, A. Krempler, P.A. Jeggo, M. Löbrich, ATM and Artemis promote homologous recombination of radiation-induced DNA double-strand breaks in G2, EMBO J. 28 (2009) 3413-3427.

[33] M. Bellamri, L. Le Hegarat, L. Vernhet, G. Baffet, R.J. Turesky, S. Langouët, Human T lymphocytes bioactivate heterocyclic aromatic amines by forming DNA adducts, Environ. Mol. Mutagen. 57 (2016) 656-667.

[34] J. Bausinger, P. Schütz, A.L. Piberger, G. Speit, Further characterization of benzo[a]pyrene diol-epoxide (BPDE)-induced comet assay effects, Mutagenesis. 31 (2016) 161-169.

[35] V. Duursen, M.B. M, J.T. Sanderson, M. van den Berg, Cytochrome P450 1A1 and 1B1 in Human Blood Lymphocytes Are Not Suitable as Biomarkers of Exposure to Dioxinlike Compounds: Polymorphisms and Interindividual Variation in Expression and Inducibility, Toxicol. Sci. 85 (2005) 703-712.

[36] K. Shiizaki, M. Kawanishi, T. Yagi, Modulation of benzo[a]pyrene-DNA adduct formation by CYP1 inducer and inhibitor, Genes Environ. 39 (2017).

[37] S. Uno, T.P. Dalton, N. Dragin, C.P. Curran, S. Derkenne, M.L. Miller, H.G. Shertzer, F.J. Gonzalez, D.W. Nebert, Oral benzo[a]pyrene in Cyp1 knockout mouse lines: CYP1A1 important in detoxication, CYP1B1 metabolism required for immune damage independent of total-body burden and clearance rate, Mol. Pharmacol. 69 (2006) 11031114.

[38] J.T. Buters, S. Sakai, T. Richter, T. Pineau, D.L. Alexander, U. Savas, J. Doehmer, J.M. Ward, C.R. Jefcoate, F.J. Gonzalez, Cytochrome P450 CYP1B1 determines susceptibility to 7, 12-dimethylbenz[a]anthracene-induced lymphomas, Proc. Natl. Acad. Sci. U. S. A. 96 (1999) 1977-1982.

[39] C. Genies, A. Maître, E. Lefèbvre, A. Jullien, M. Chopard-Lallier, T. Douki, The Extreme Variety of Genotoxic Response to Benzo[a]pyrene in Three Different Human Cell Lines from Three Different Organs, PLOS ONE. 8 (2013) e78356.

[40] A. Ciccia, J.-W. Huang, L. Izhar, M.E. Sowa, J.W. Harper, S.J. Elledge, Treacher Collins syndrome TCOF1 protein cooperates with NBS1 in the DNA damage response, Proc. Natl. Acad. Sci. U. S. A. 111 (2014) 18631-18636. 
[41] H.S. Madapura, D. Salamon, K.G. Wiman, S. Lain, G. Klein, E. Klein, N. Nagy, p53 contributes to $\mathrm{T}$ cell homeostasis through the induction of pro-apoptotic SAP, Cell Cycle. 11 (2012) 4563-4569.

[42] B. Binková, Y. Giguère, P. Rössner Jr., M. Dostál, R.J. Šrám, The effect of dibenzo[a,1]pyrene and benzo[a]pyrene on human diploid lung fibroblasts: the induction of DNA adducts, expression of p53 and p21WAF1 proteins and cell cycle distribution, Mutat. Res. Toxicol. Environ. Mutagen. 471 (2000) 57-70.

[43] M. Christmann, C. Boisseau, R. Kitzinger, C. Berac, S. Allmann, T. Sommer, D. Aasland, B. Kaina, M.T. Tomicic, Adaptive upregulation of DNA repair genes following benzo(a)pyrene diol epoxide protects against cell death at the expense of mutations, Nucleic Acids Res. 44 (2016) 10727-10743.

[44] K. Myers, M.E. Gagou, P. Zuazua-Villar, R. Rodriguez, M. Meuth, ATR and Chk1 suppress a caspase-3-dependent apoptotic response following DNA replication stress, PLoS Genet. 5 (2009) e1000324.

[45] S. Sidi, T. Sanda, R.D. Kennedy, A.T. Hagen, C.A. Jette, R. Hoffmans, J. Pascual, S. Imamura, S. Kishi, J.F. Amatruda, J.P. Kanki, D.R. Green, A.A. D'Andrea, A.T. Look, Chk1 suppresses a caspase-2 apoptotic response to DNA damage that bypasses p53, Bcl2, and caspase-3, Cell. 133 (2008) 864-877.

[46] M. Christmann, B. Kaina, Transcriptional regulation of human DNA repair genes following genotoxic stress: trigger mechanisms, inducible responses and genotoxic adaptation, Nucleic Acids Res. 41 (2013) 8403-8420.

[47] F.N. Papavasiliou, D.G. Schatz, Cell-cycle-regulated DNA double-strand breaks in somatic hypermutation of immunoglobulin genes, Nature. 408 (2000) 216-221. 
Fig.1

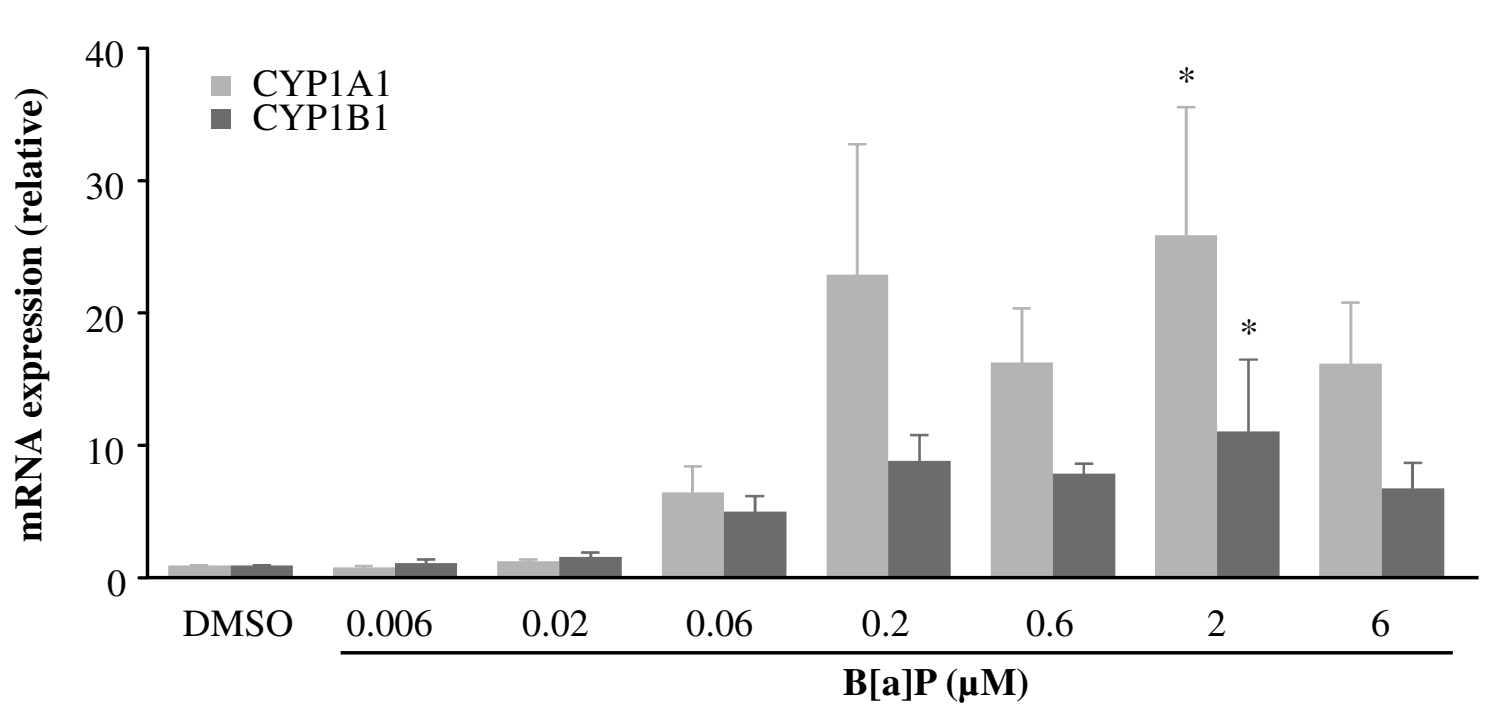

B

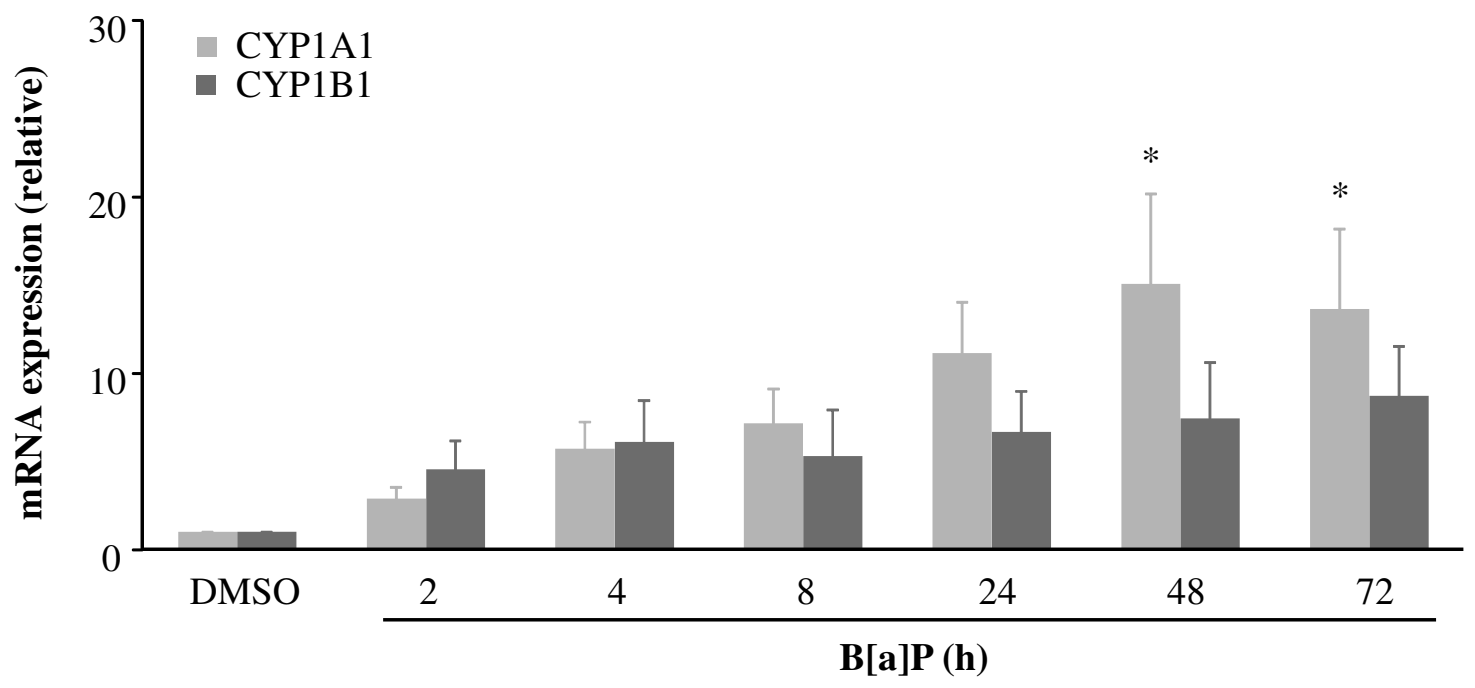

C
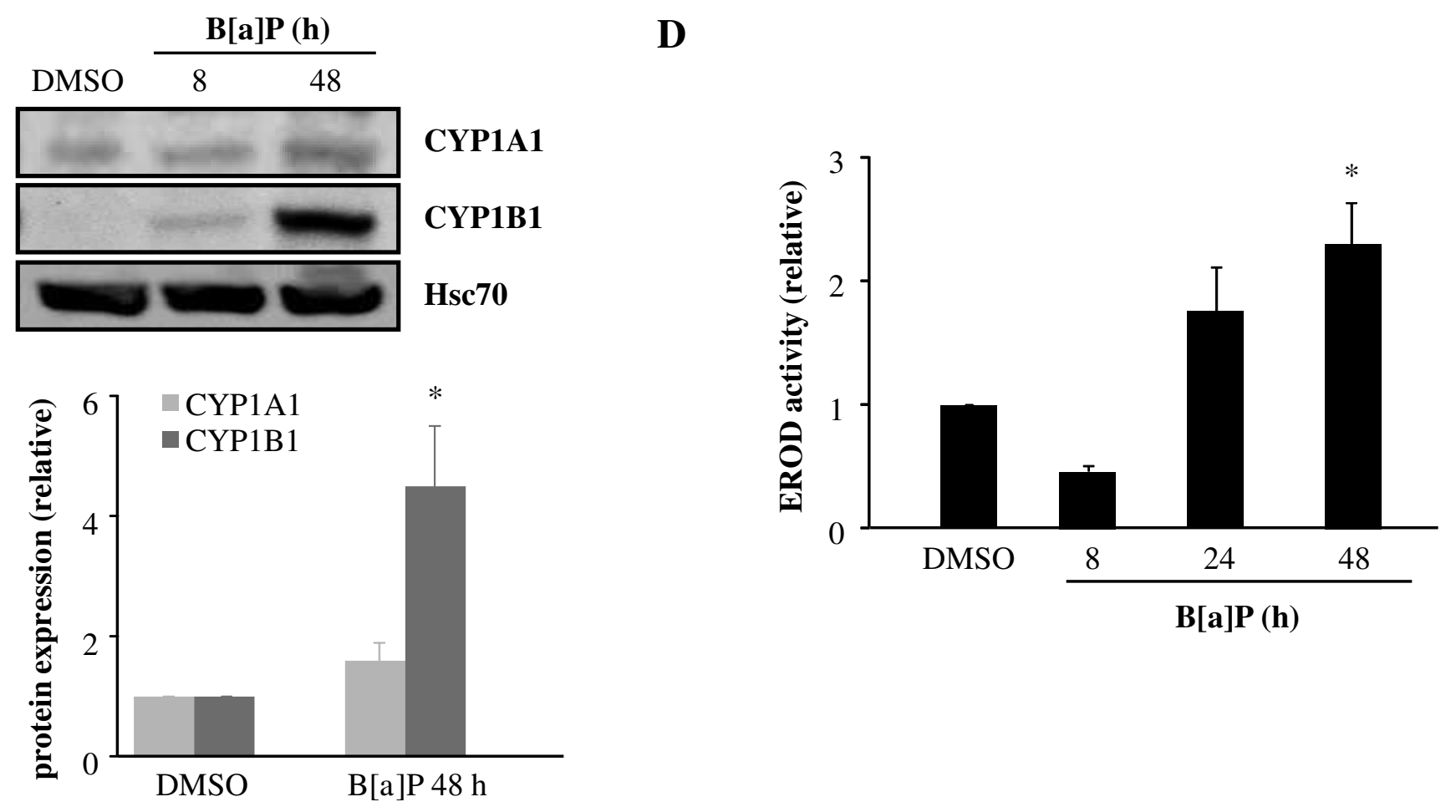

Fig. 1 
Fig.2

A

dG-N²-BPDE DNA adducts

for $10^{6}$ nucleosides

\begin{tabular}{lc}
\hline DMSO & not detected \\
\hline B[a]P $8 \mathrm{~h}$ & not detected \\
\hline B[a]P 48h & $7.12 \pm 2$ \\
\hline
\end{tabular}

B

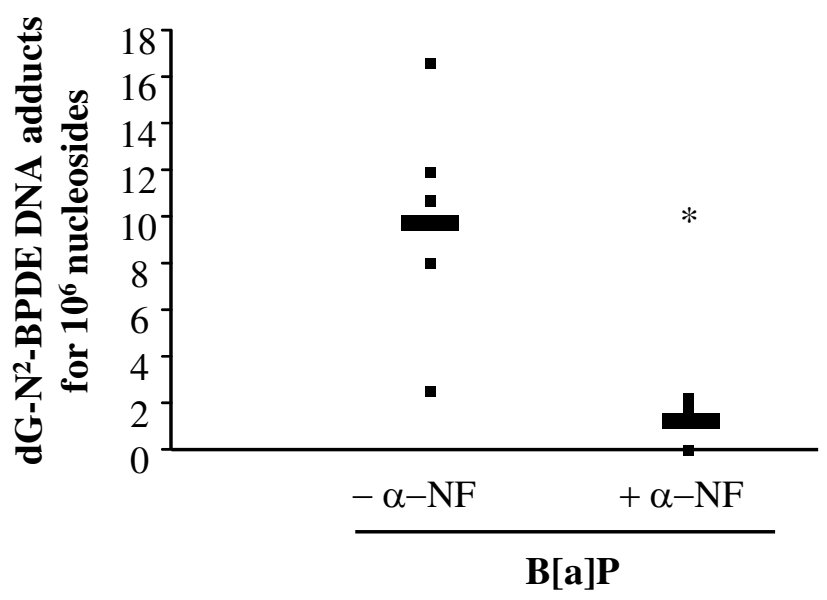

Fig. 2 
Fig. 3

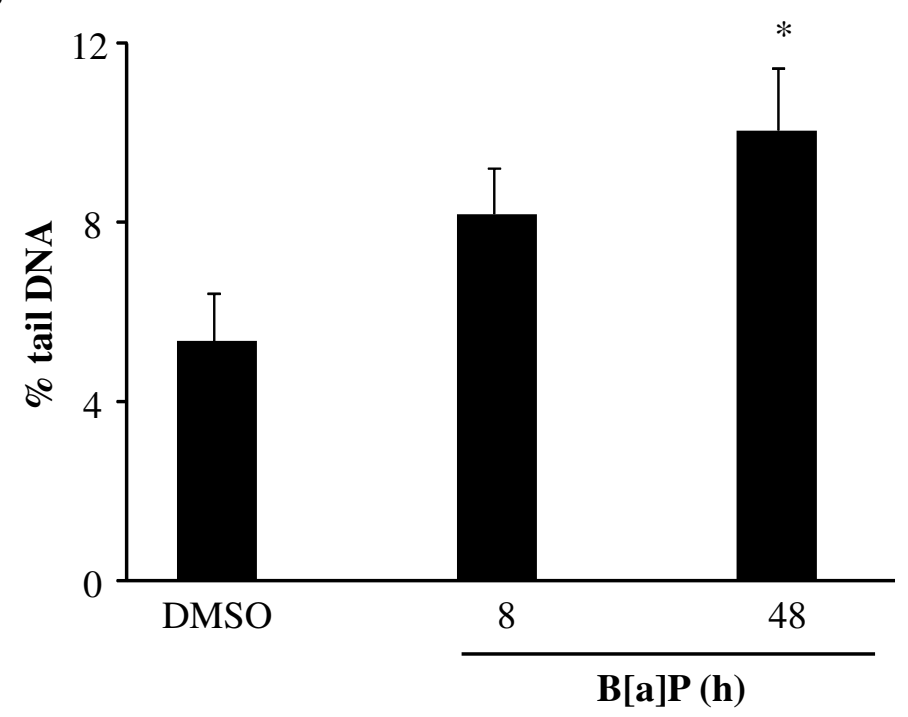

B

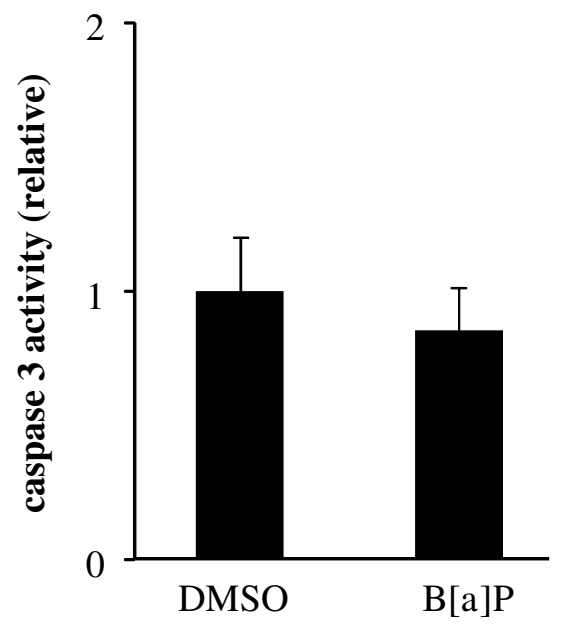

C

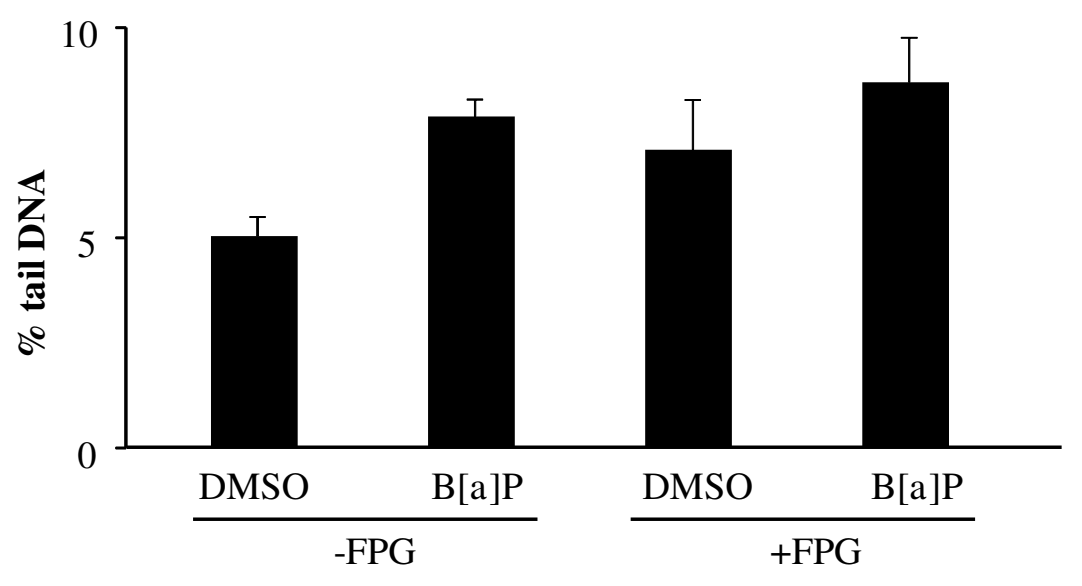

D

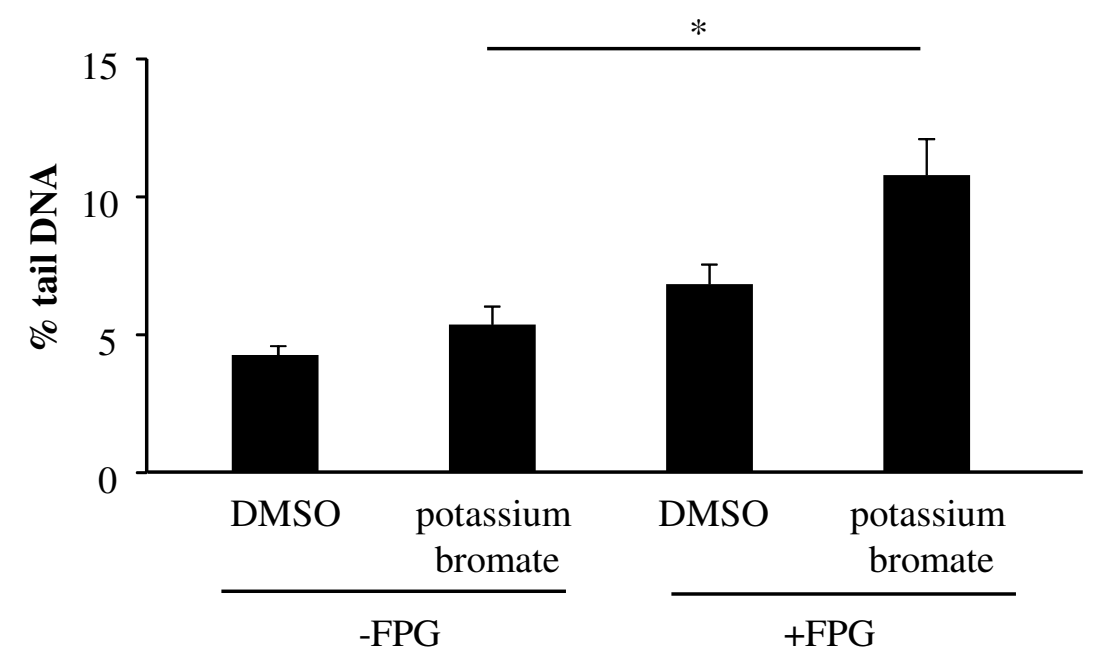

Fig. 3 
Fig.4

A

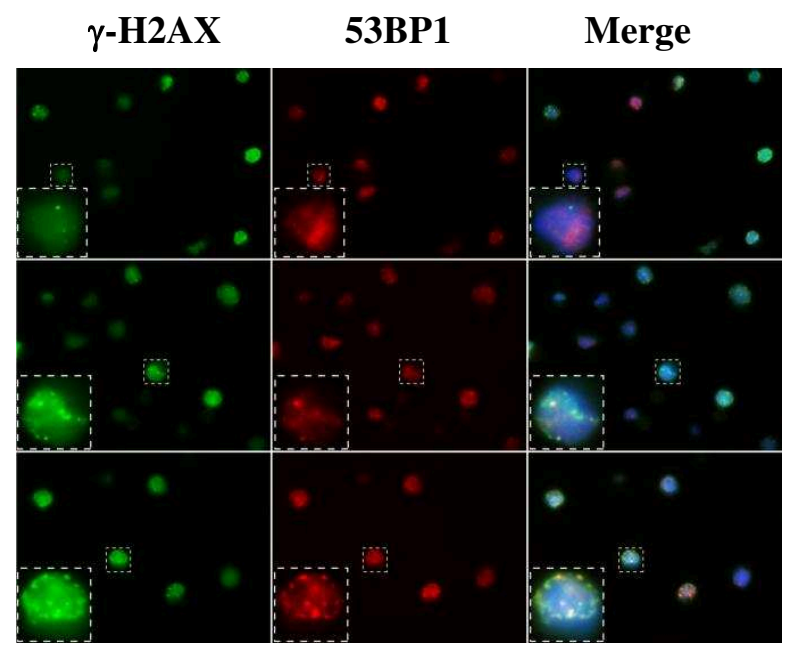

DMSO

$48 \mathrm{~h}$ B [a]P

8 h B [a]P
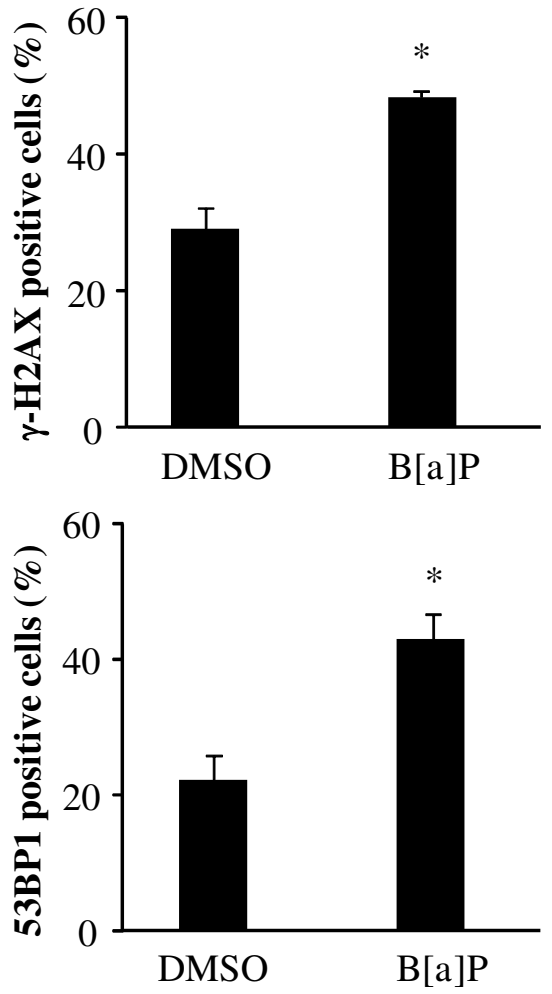

C
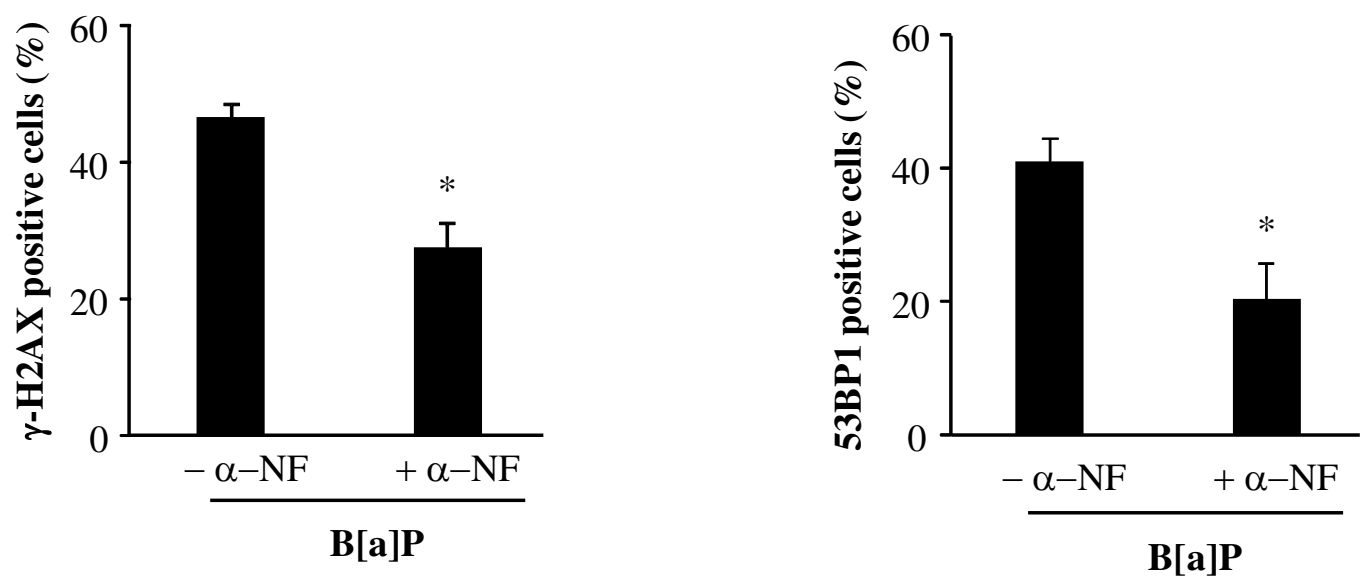

Fig. 4 
År DMSO B[a]P
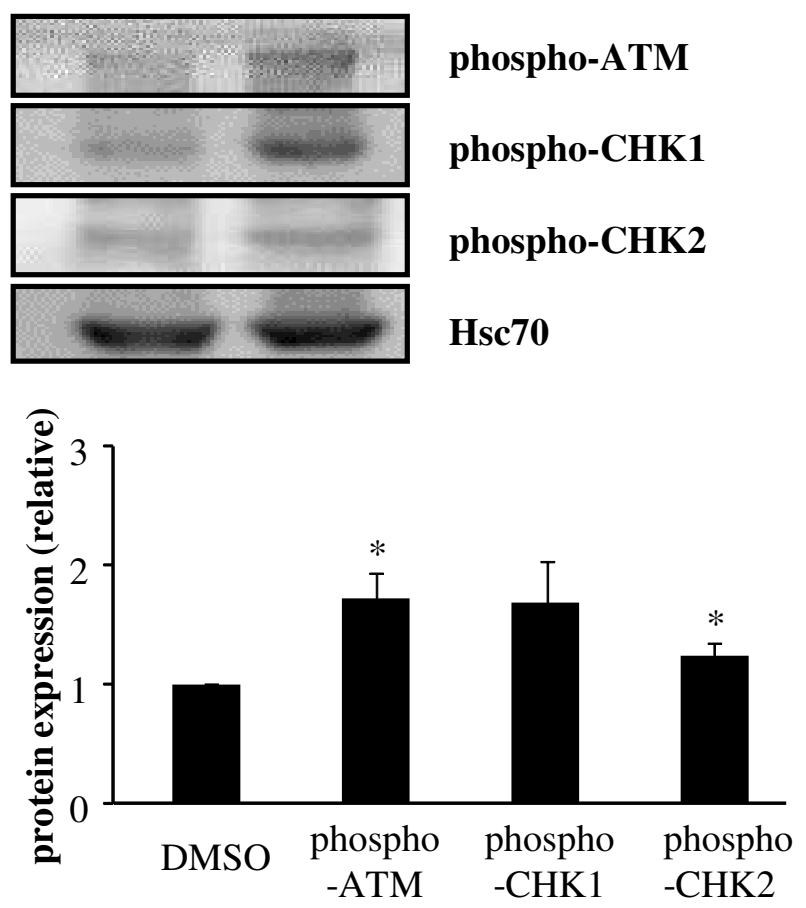

C

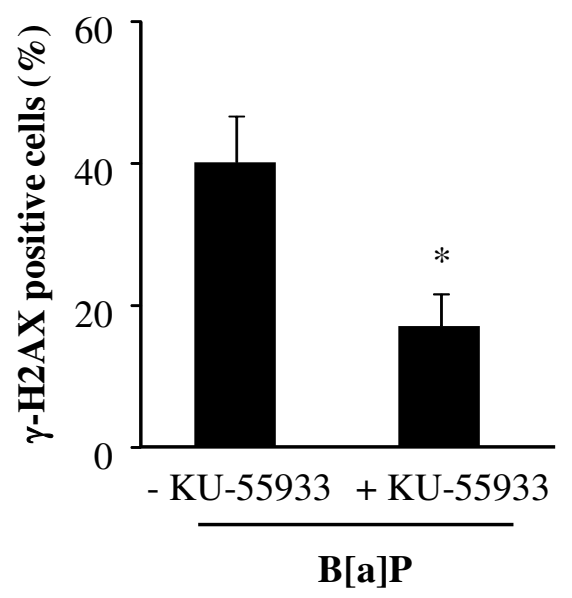

$\mathbf{E}$

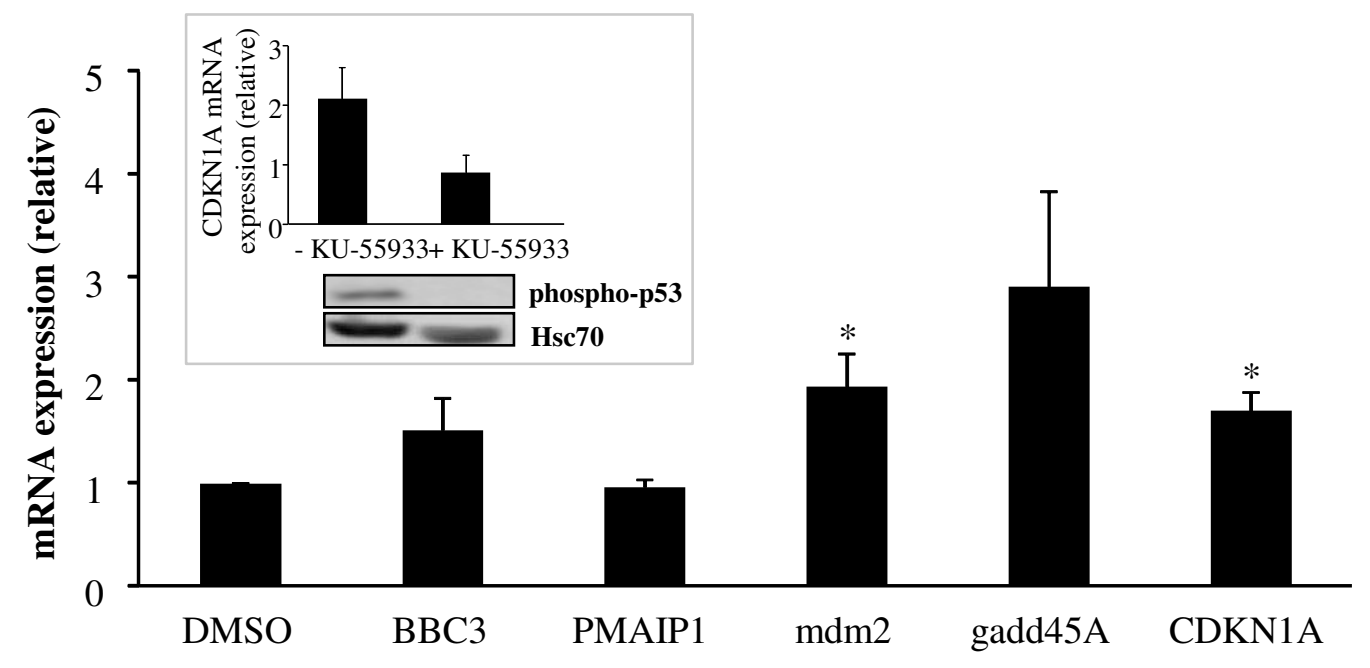

Fig. 5

$\mathbf{E}$
B

phospho-ATM

phospho-CHK1

phospho-CHK2

Hsc70
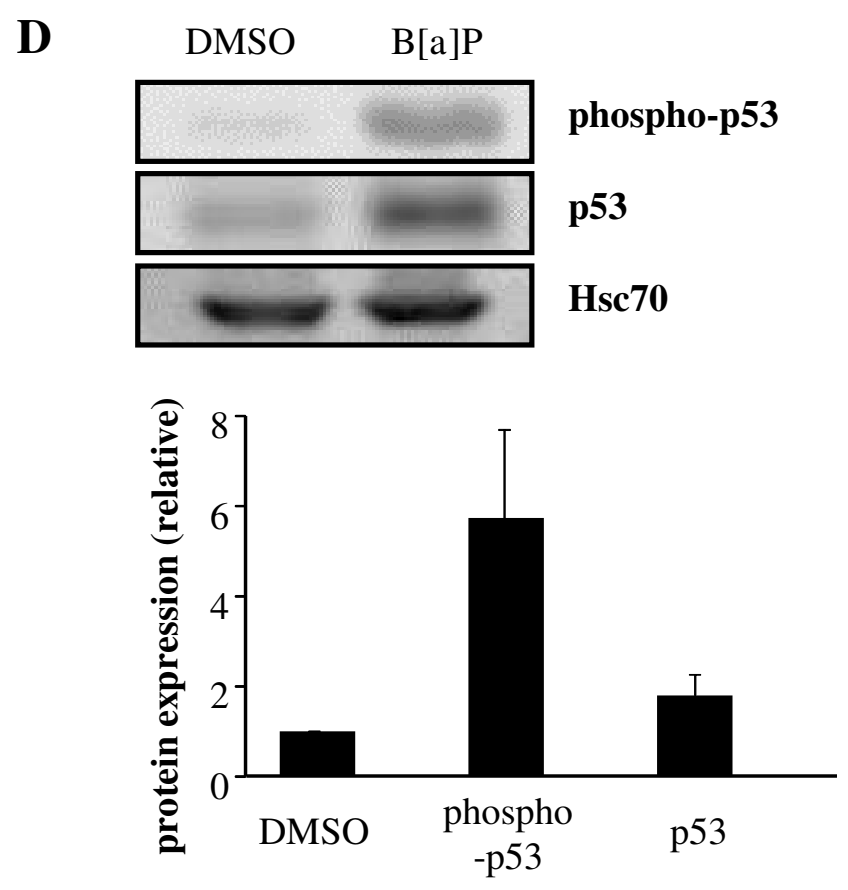

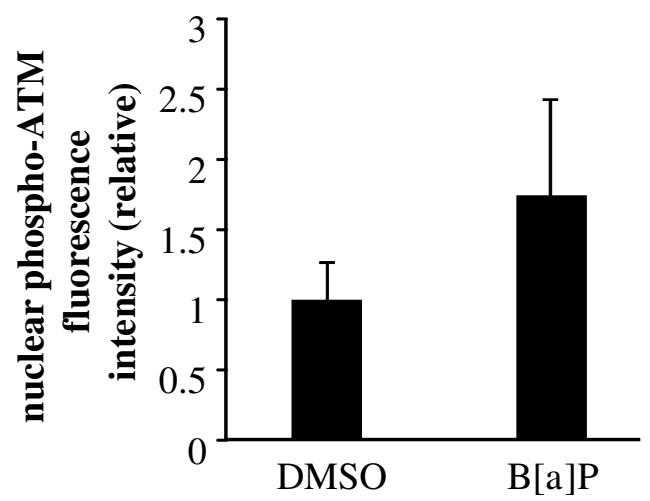

Hsc70 
A

DMSO B[a]P

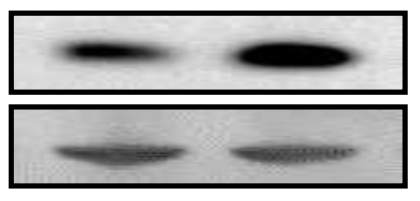

p21

Hsc70
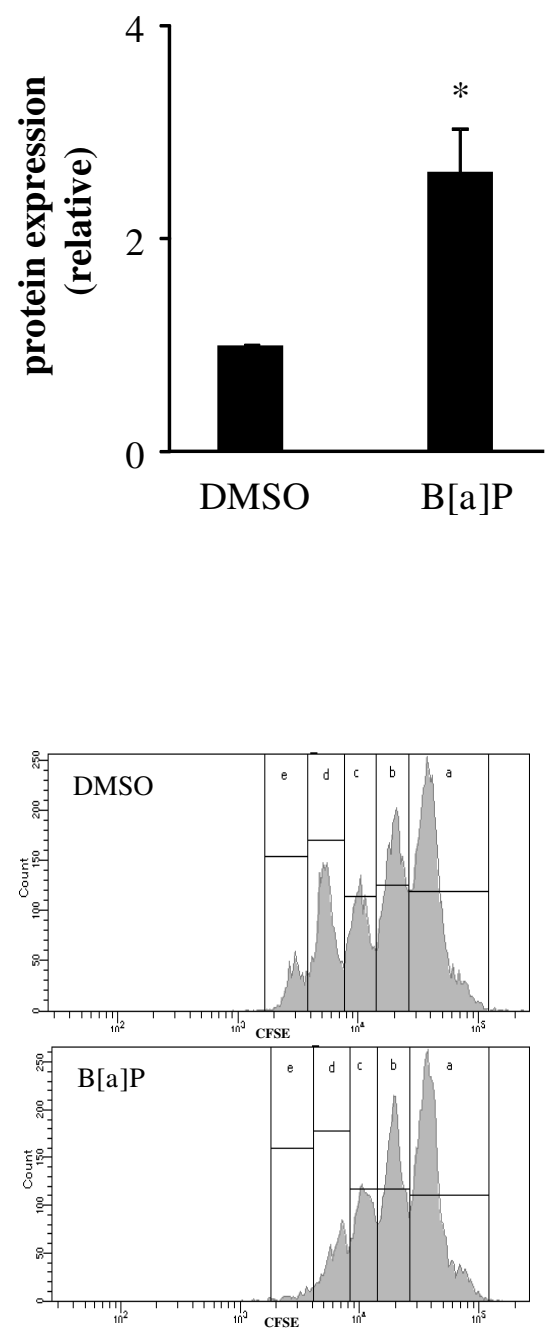
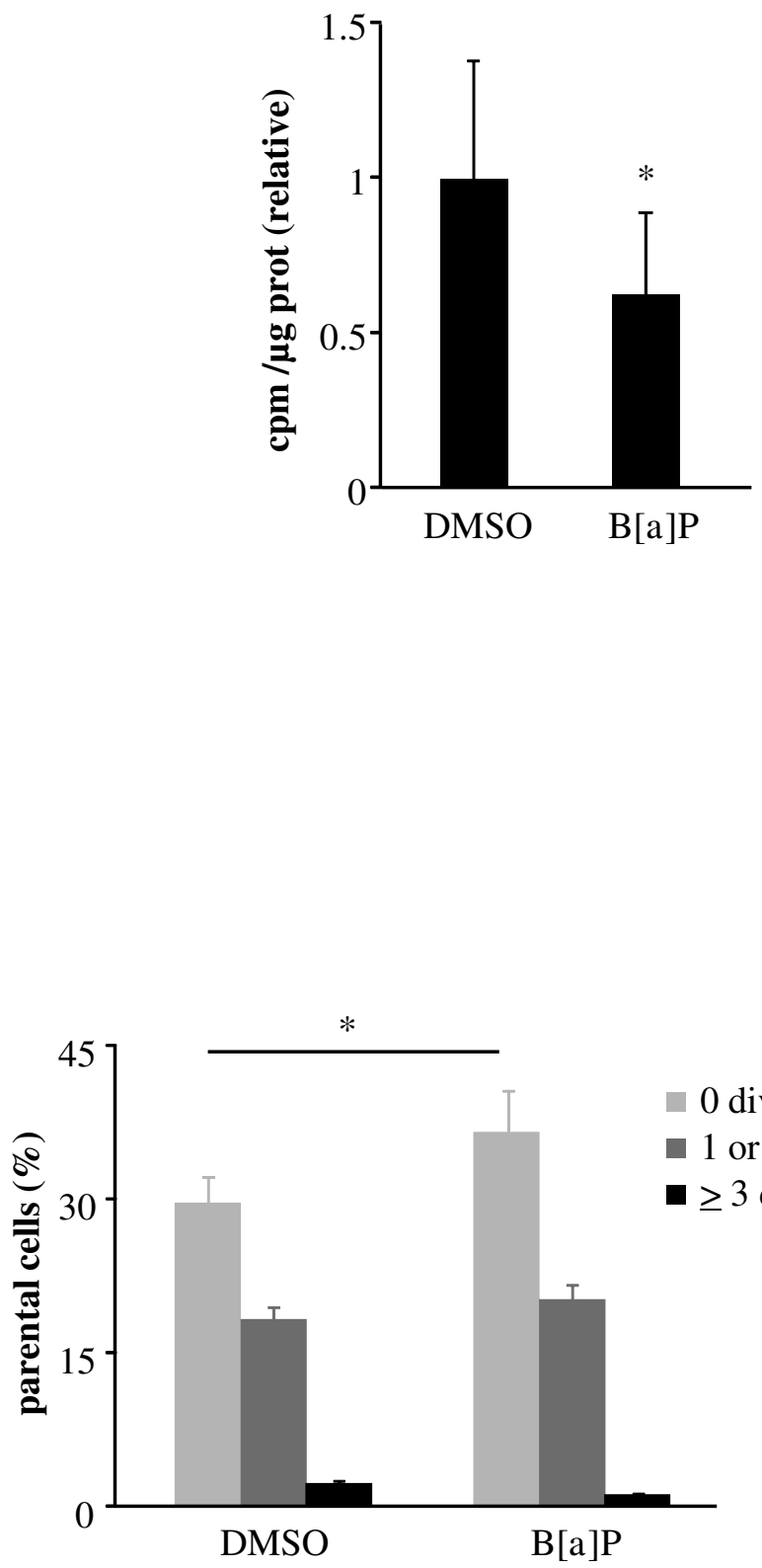


\begin{tabular}{c|c|c}
\hline Symbol Gene & Fold Change & Functional Group \\
\hline ERCC6 & 2.13 & nucleotide excision repair \\
\hline TDG & 1.93 & base excision repair \\
\hline ERCC4 & 1.81 & nucleotide excision repair \\
\hline ERCC3 & 1.75 & nucleotide excision repair \\
\hline XRCC1 & 1.68 & base excision repair \\
\hline MRE11A & 1.67 & homologous recombination \\
\hline XRCC5 & 1.63 & mismatch repair \\
\hline MLH1 & 1.62 & mismatch repair \\
\hline PMS2 & 1.61 & homoleotide excision repair \\
\hline RAD23B & 1.56 & nucleotide excision repair \\
\hline BRCA1 & 1.54 & homologous recombination \\
\hline SLK & 1.53 & homologous recombination \\
\hline BRIP1 & 1.53 &
\end{tabular}

B
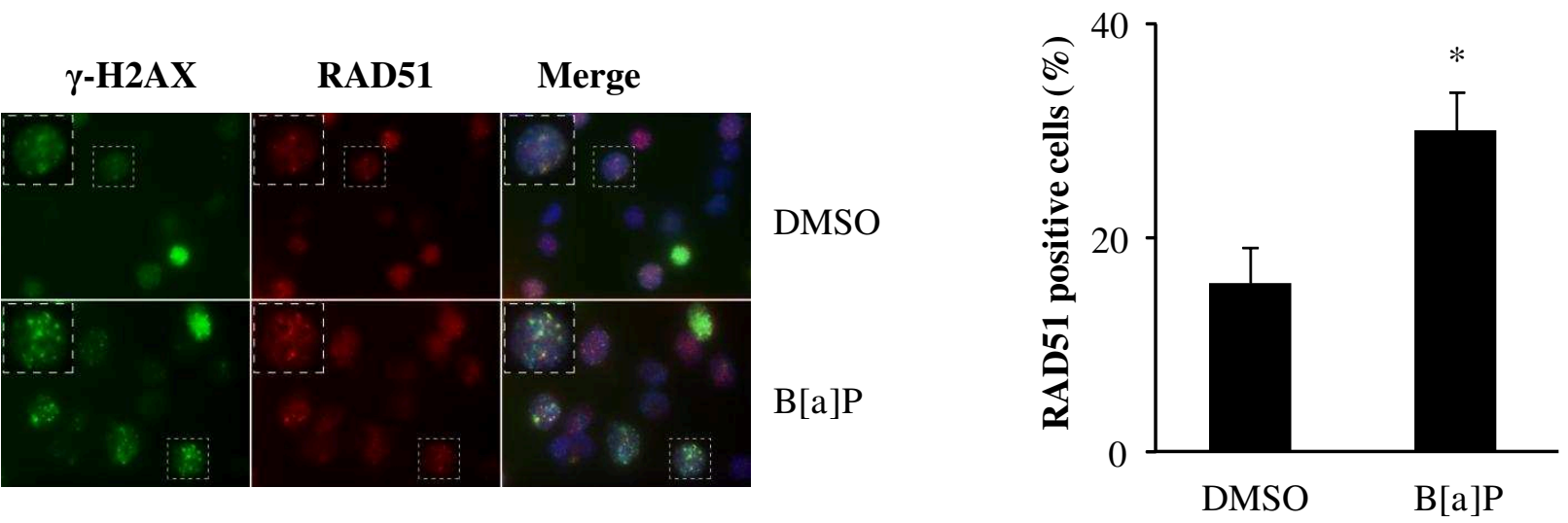

C

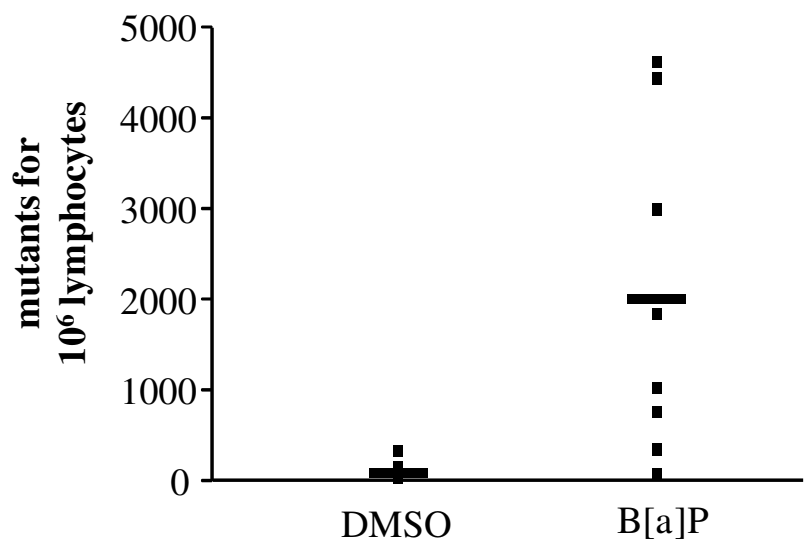

Fig. 7 
Table 1: Primer sequences for RT-qPCR

\begin{tabular}{lll}
\hline Gene Symbol & Forward Sequence & Reverse Sequence \\
\hline & & \\
mdm2 & GCAGTGAATCTACAGGGACGC & ATCCTGATCCAACCAATCACC \\
CDKN1A & GGCAGACCAGCATGACAGATT & GGCGGCCAGGGTATGTA \\
BBC3 & GACCTCAACGCACAGTACGA & GAGATTGTACAGGACCCTCCA \\
PMAIP1 & GGAGATGCCTGGGAAGAAG & CCTGAGTTGAGTAGCACACTCG \\
18S & CGCCGCTAGAGGTGAAATTC & TTGGCAAATGCTTTCGCTC
\end{tabular}




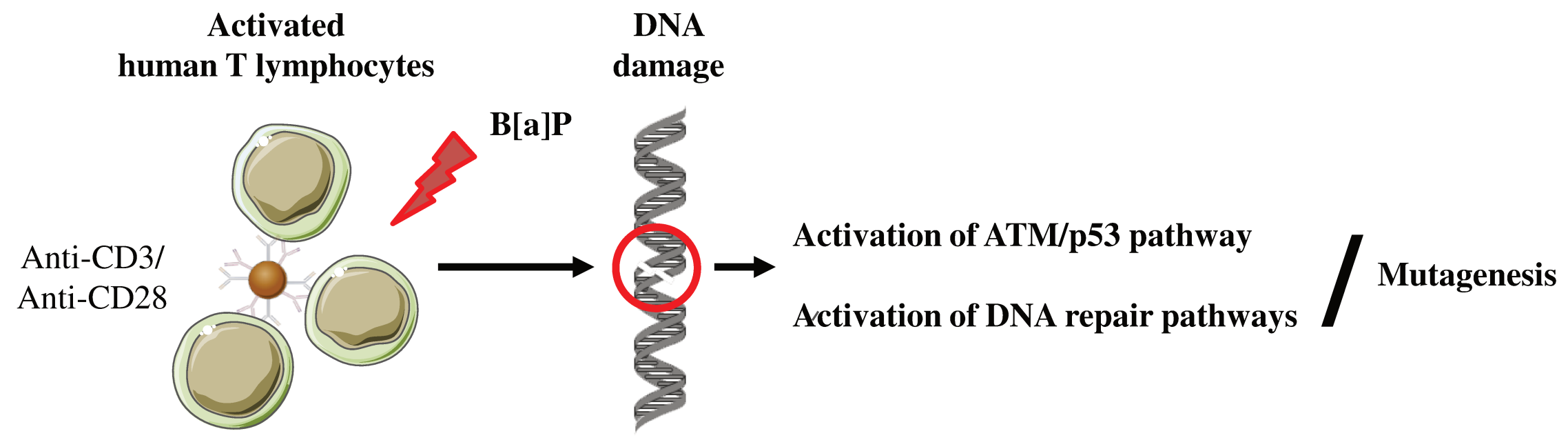

